\title{
Neuroendocrine Regulation of GnRH Release in Induced Ovulators
}

\author{
J ulie Bakker and Michael J. Baum
}

Department of Biology, Boston University, 5 Cummington Street, Boston, Massachusetts 02215

$\mathrm{GnRH}$ is the key neuropeptide controlling reproductive function in all vertebrate species. Two different neuroendocrine mechanisms have evolved among female mammals to regulate the mediobasal hypothalamic $(\mathrm{MBH})$ release of $\mathrm{GnRH}$ leading to the preovulatory secretion of LH by the anterior pituitary gland. In females of spontaneously ovulating species, including rats, mice, guinea pigs, sheep, monkeys, and women, ovarian steroids secreted by maturing ovarian follicles induce a pulsatile pattern of GnRH release in the median eminence that, in turn, stimulates a preovulatory LH surge. In females of induced ovulating species, including rabbits, ferrets, cats, and camels, the preovulatory release of $\mathrm{GnRH}$, and the resultant preovulatory LH surge, is induced by the receipt of genital somatosensory stimuli during mating. I nduced ovulators generally do not show "spontaneous" steroid-induced LH surges during their reproductive cycles, suggesting that the positive feedback actions of steroid hormones on GnRH release are reduced or absent in these species. By contrast, mating-induced preovulatory surges occasionally occur in some spontaneously ovulating species. Most research in the field of $\mathrm{GnRH}$ neurobiology has been performed using spontaneous ovulators including rat, guinea pig, sheep, and rhesus monkey. This review summarizes the literature concerning the neuroendocrine mechanisms controlling $\mathrm{GnRH}$ biosynthesis and release in females of several induced ovulating species, and whenever possible it contrasts the results with those obtained for spontaneously ovulating species. It also considers the adaptive, evolutionary benefits and disadvantages of each type of ovulatory control mechanism. In females of induced ovulating species estradiol acts in the brain to induce aspects of proceptive and receptive sexual behavior. The primary mechanism involved in the preovulatory release of GnRH among induced ovulators involves the activation of midbrain and brainstem noradrenergic neurons in response to genital-somatosensory signals generated by receipt of an intromission from a male during mating. These noradrenergic neurons project to the $\mathrm{MBH}$ and, when activated, promote the release of $\mathrm{GnRH}$ from nerve terminals in the median eminence. In contrast to spontaneous ovulators, there is little evidence that endogenous opioid peptides normally inhibit MBH $\mathrm{GnRH}$ release among induced ovulators. Instead, the neural signals that induce a preovulatory LH surge in these species seem to be primarily excitatory. A complete understanding of the neuroendocrine control of ovulation will only be achieved in the future by comparative studies of several animal model systems in which mating-induced as well as spontaneous, hormonally stimulated activation of GnRH neurons drives the preovulatory LH surge. KEY WORDS: GnRH; MBH; induced ovulators; neuroendocrine regulation; preovulatory LH surge; spontaneous ovulators. ๑ 2000 Academic Press

Address correspondence and reprint requests to M. J . Baum at Dept. Biology, Boston University, 5 Cummington Street, Boston, MA 02215. E-mail: baum@bio.bu.edu.. 


\section{INTRODUCTION}

Females of induced ovulating mammalian species (e.g., voles, rabbits, mink, ferrets, cats, and camels) undergo periods of behavioral estrus when ovulation is induced by sensory stimulation associated with mating. By contrast, females of spontaneously ovulating species (e.g., rats, hamsters, guinea pigs, sheeps, monkeys, and humans) undergo ovarian cycles in which ovulation is induced by ovarian steroid hormones at regular intervals. Many have argued that this classification of species into either "induced" or "spontaneous" ovulators is too rigid $(46,104$, 152, 251). There are numerous examples of coitus-induced or coitusfacilitated ovulation in spontaneously ovulating species. The laboratory rat and mouse are probably the best examples of species in which both ovulatory mechanisms appear to be integrated. The female rat must receive intromissive stimulation in order for the ovaries to devel op fully functional corpora lutea. Mating stimulates the release of prolactin from the anterior pituitary which is necessary for luteal activity (reviewed in 212). In addition, female rats exhibiting persistent vaginal estrus either spontaneously at middle age (69) or after exposure to constant light (56) may show coitus-induced ovulation. The spontaneously mutant hpg mouse (37), which bears a specific deletion in the GnRH gene, showed mating-induced but not spontaneous ovulation when brain grafts containing $\mathrm{GnRH}$ neurons were implanted into the third ventricle (77). In cattle $(141,204)$, mating during the first 6-8 $\mathrm{h}$ of behavioral estrus advanced the preovulatory LH surge and resultant ovulation. Taken together, these observations suggest that the neural circuitry underlying the reflexive release of LH is present in some spontaneously ovulating species. By contrast, induced ovulating species generally do not show steroid-induced preovulatory LH surges. Regimens of estradiol treatment, either with or without concurrent progesterone, that successfully induced LH surges in rats failed to stimulate LH secretion in rabbits (197), voles $(149,150)$, or ferrets (12). The cat seems to be an exception to this rule in which spontaneous ovulations have been observed occasionally in group-housed females $(85,123)$. Taken together, the available data suggest that positive feedback actions of steroid hormones on gonadotropin release are either reduced or absent in induced ovulating species.

This review will summarize what is known about the neuroendocrine mechanisms controlling the preovulatory LH surge among induced ovulating species. These mechanisms involve ovarian steroid hormones, sensory inputs resulting from mating, the forebrain $\mathrm{GnRH}$ neurons and the network of neurons which control the release of $\mathrm{GnRH}$ into the pituitary portal vessels, and the pituitary gonadotrophs, which respond to $\mathrm{GnRH}$ by releasing LH. In addition, we will discuss some of the main differences and similarities between the neuroendocrine mechanisms controlling induced versus spontaneous ovulation. 




Adapted from Jones et al. (Fertility and Sterility 1976; 27: 848-852).

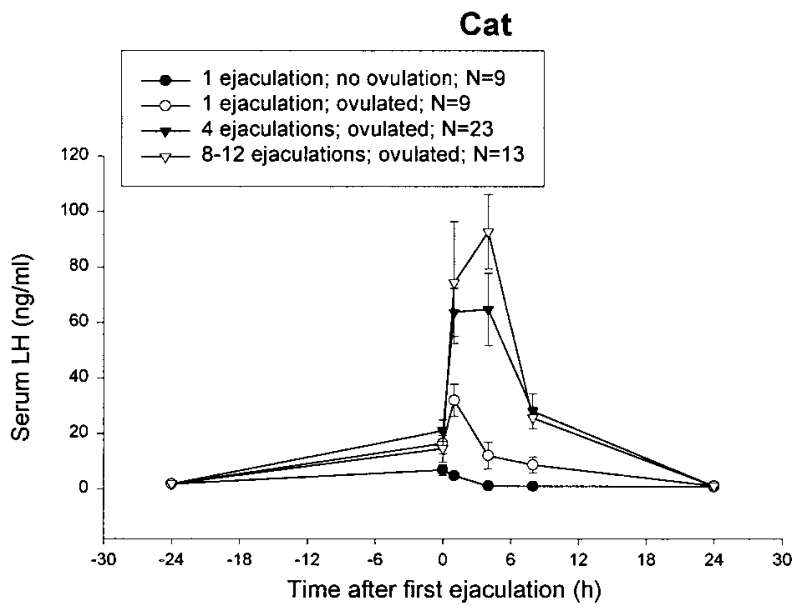

Adapted from Concannon et al. (Biol Reprod 1980; 23: 111-117)

\section{Ferret}

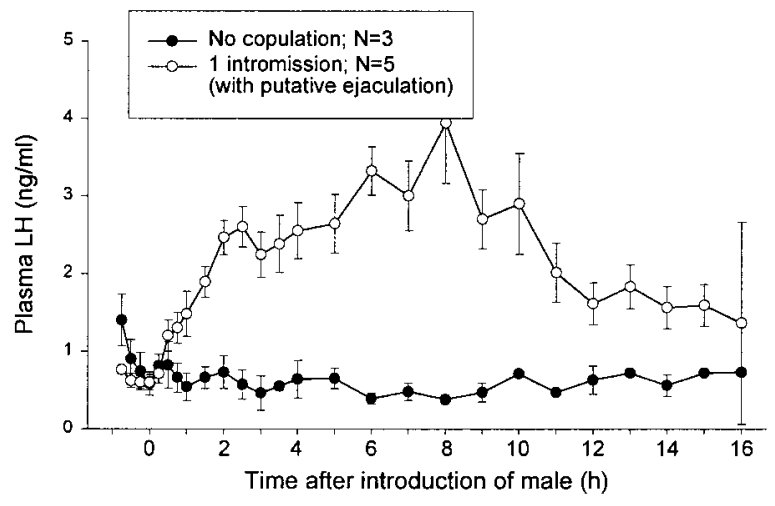

Adapted from Carroll et al. (Biol Reprod 1985; 32: 925-933) 


\section{CHARACTERISTICS OF THE LH SURGE}

\section{The Preovulatory LH Surge}

The primary endocrine response to coitus in induced ovulators is an immediate release of $\mathrm{LH}$ from the anterior pituitary that results in ovulation. There is some species variability in the pattern of mating behavior preceding a preovulatory surge in LH and in the latency, duration, and magnitude of this LH peak after mating. To date, the coitus-induced LH surge has been characterized in rabbits (Oryctolagus cuniculus; 64, 80, 105), voles (Microtinae; 38), cats (F el is catus; 47, 107, 238), ferrets (Mustela furo; 33), and camels (Camelus dromedarius; 140). However, the relationship between the amount of mating stimulation received and the resultant preovulatory LH surge has been studied systemically only in cats $(47,107$, 238) and ferrets (33). Typically, the postcoital rise in LH can be defined either as an "all-or-none" response to the first effective stimulus or as a more cumulative response to the amount of mating stimulation received. In the ferret (33), a single intromission induced a prolonged preovulatory $\mathrm{LH}$ surge in the estrous female. This elevation in plasma LH levels began around $1.5 \mathrm{~h}$ after the onset of intromission, reached a maximum approximately $6 \mathrm{~h}$ later, and was sustained for at least $12 \mathrm{~h}$ (33; Fig. 1). Even though intromission duration varied from 1 to $94 \mathrm{~min}$, ovaries of every ferret receiving an intromission had corpora lutea 1 week later. Thus, the preovulatory surge in $\mathrm{LH}$ in the ferret seems to be independent of the amount of mating stimulation received and is therefore an all-or-none phenomenon. Likewise, in the mink (Mustela vision; 67), ovulation can be induced by receipt of an intromission as short as $2 \mathrm{~min}$. Although no data are currently available on plasma LH levels after mating in this species, a single intromission presumably suffices to induce a preovulatory LH surge. In the rabbit (105), a short mating bout including ejaculation induces a rapid release of LH from the pituitary. Plasma LH levels started to rise within 3 min after receipt of an ejaculation and reached a plateau within 15 min (105; Fig. 1). By contrast, in the cat $(47,107,238)$ the duration and magnitude of the LH surge are related to the amount of coital stimulation received (Fig. 1). In cats (107), plasma LH levels increased rapidly after a single mating and peaked 20 min later. The pattern of the single matinginduced LH release was very similar to that occurring after a single injection of GnRH (106). However, a single mating bout induced ovulation in only $50 \%$ of the females studied $(47,238)$. When female cats were allowed

FIG. 1. Changes in serum or plasma LH levels following receipt of intromission with ejaculation in the rabbit, cat, and ferret. In both rabbit and ferret, the magnitude of the preovulatory $\mathrm{LH}$ surge is independent of the amount of mating stimulation received. By contrast, in the cat the duration and magnitude of the LH surge is related to the amount of mating stimulation received. Data are represented as means \pm SEM. 
to receive multiple ejaculations or to mate at their own pace, plasma LH levels were significantly higher compared to those of once-mated cats, and all cats ovulated $(47,107,238)$. Therefore in contrast to ferrets and minks, in cats repeated copulations probably trigger episodes of $\mathrm{GnRH}$ release, thereby producing cumulative increments in plasma LH levels.

\section{Stimulus Requirements for Inducing a Preovulatory LH Surge}

In most induced ovulating species, stimulation of the female's genital tract by penile intromission from a male conspecific most effectively induces the preovulatory release of LH from the pituitary, although there are reports (1, 67) of ovulation occurring in female mink after brief exposure to a male in the absence of actual intromission. The amount of mating stimulation required to induce a preovulatory LH surge is usually much less than what is normally provided during copulation. F or example, voles (57, 152), rabbits (158), and cats (23) all copulate in bouts which involve multiple intromissions and ejaculations. Despite this extensive copulatory activity, the effective stimulus for inducing ovulation is just a single intromission in Microtus agrestis (148) and a single ejaculatory series in Microtus montanus (116). Likewise, in rabbits (158), al pacas (73), and racoons (233), only one ejaculation was required to induce ovulation in the majority of animals. By contrast, female prairie voles (Microtus ochrogaster; 34$)$ and cats $(47,107,238)$ must receive multiple intromissions and ejaculations in order to ovulate.

Shrews (Order Insectivora) are the only induced ovulating species known to require extensive mating stimulation over a period of at least $24 \mathrm{~h}$ to induce ovulation. When female musk shrews (Suncus murinus) were mated for less than $4 \mathrm{~h}$, only one third of the females ovulated (181). However, when female musk shrews received multiple intromissions and ejaculations over at least $24 \mathrm{~h}$, all animals ovulated (55). Likewise, in the least shrew (Cryptotis parva; 154), copulatory activity lasting 12-36 h was needed to induce ovulation. Thus the reproductive physiol ogy of shrews does not seem to resemble that of classic induced ovulating species, in which mating readily induces a preovulatory $\mathrm{LH}$ surge leading to ovulation.

\section{Evolution of Induced Ovulation}

The occasional occurrence of induced ovulation in species generally known as spontaneous ovulators inspired the hypothesis $(46,251)$ that induced ovulation is a primitive characteristic from which spontaneous ovulation has evolved. J öchle (104) extended this concept even further by proposing that all mammalian species, including human, can show coitus-induced ovulation on specific (usually adverse) occasions ("facultative-induced ovulators"). This would suggest that this primitive trait has been conserved among higher 




FIG. 2. Phylogenetic distribution of induced ovulation among mammalian species. Induced ovulating species have been found among the Orders Lagomorpha, Rodentia, Insectivora, Carnivora, and Artiodactyla (solid boxes). Additional species that have been suggested to be induced ovulators belong to the Orders Chiroptera and Cetacea (dotted boxes).

mammals. It should be noted that the occurrence of coitus-induced ovulation and conception in women is mostly based on circumstantial evidence such as reports of pregnancies in victims of rape and women with amenorrhoea, and thus is quite controversial $(103,104)$. One could argue that rape victims who become pregnant are more likely to report the crime to the police than those who do not.

The widespread occurrence of induced ovulation in the primitive Order Insectivora and in Rodentia supports the notion that induced ovulation is a primitive trait $(46,104,251)$. Zarrow and Clarke (251) further argued that its occurrence in Insectivora, Lagomorpha, and Rodentia reflects the relatively close phylogenetic relationship among these orders and that the occurrence of induced ovulation in some Carnivores reflects its early separation from the Ungulates (Fig. 2). However, this cannot explain the occurrence of induced ovulation in the Camelidae. Also, if induced ovulation is a primitive trait, one would expect it to be the prevailing ovulatory mechanism among nonmammalian vertebrates, such as fish, amphibians, reptiles, and birds, as well as among the more primitive mammals, the monotremes and marsupials. This is not the case. Generally, nonmammalian vertebrates show "spontaneous" steroid-induced ovulation. Only the red-sided garter snake (145) has been identified as an induced ovulator among nonmammalian vertebrates. In addition, there is one report (6) suggesting that the marsupial species Potorous tridactylus is an induced ovulator. It should be noted, however, that our knowledge of the reproductive strategies of most vertebrate species is still very limited. 
It has been suggested $(70,152)$ that induced ovulation evolved on at least two separate occasions. This trait probably evolved after the evolutionary lines of the marsupials and eutharians separated during the early Cretaceous period (>100 million years ago; Fig. 2). Induced ovulation may have evolved as a special case of male-induced activation of the GnRH neuronal system in females of several species. There are numerous examples among mammals (reviewed in 26, 189, 234), birds (reviewed in 98, 127), and reptiles (reviewed in 49) in which the display of behaviors by a male stimulates gonadotropin secretion and consequent ovarian development and sexual behavior in female conspecifics. For instance, introducing males into a group of seasonally anestrous female goats induced estrous cycles and subsequent (spontaneous) ovulation (39). This "male-effect" in goats most likely reflects a pheromoneinduced activation of GnRH release (87). Similarly, pheromonal cues derived from males induce estrus in female mice (142) and female gray short-tailed opossums (Monodel phis domestica; 71). Another example of activation of the reproductive neuroendocrine system by male cues is the increase in number of female whiptail lizards (Cnemi dophorus inornatus) ovulating when a sexually active conspecific male is present (48). Interestingly, the same is true for the unisexual Cnemidophorus uniparens in the presence of a female showing male-typical sexual behavior (48). The latter emphasizes the evolutionary significance of exposure to a male for successful breeding and thus a positive selection pressure for maintaining the expression of male-typical behaviors among females.

A positive selection pressure for induced ovulation may be the resultant optimal synchronization of ovulation in the female with the provision of sperm by the male, thereby preventing any evolutionary costs associated with wastage of gametes by females. If this is true, it is surprising that induced ovulation has not evolved as the prevailing ovulatory mechanism among all vertebrates. The evolutionary disadvantage of induced ovulation might involve the absence of sperm competition, i.e., the competition between sperm ejaculated by different male partners for fertilization of a female's ova (165). Initially, sperm competition was viewed largely from a male perspective, i.e., the battle between males to mate with passively receptive females (165). It is now clear that females also play an important role in mate selection by actively choosing whether or not to mate with certain males. This suggests that females promote sperm competition because they benefit from it as well. For instance, by promoting sperm competition, females enhance the genetic quality of their offspring - on the presumption that genetically superior males produce sperm that compete most effectively in situations with sperm competition (79). Sperm competition is widespread across the animal kingdom (207), although it has been studied most extensively in Drosophila (175) and zebra finches (reviewed in 21). In insects and birds, the last male to inseminate a female before she ovulates usually fertilizes the majority of her ova. Like spontaneous ovulators, females of induced ovulating species actively choose their mating partners. F or example, female musk shrews rejected certain males but were receptive to other males which were introduced immediately before or after the rejected 
males (63). However, the time window between mating and the occurrence of ovulation in induced ovulators is probably too narrow to permit appreciable sperm competition in the female's reproductive tract (79). Although there is some variation in the interval between mating and ovulation among induced ovulating species, ovulation and fertilization typically occur within $24 \mathrm{~h}$ after mating in most species (152). Thus the first male to ejaculate with a female will usually fertilize her ova. In accordance with this first-male advantage, field data (202) from the 13-lined ground squirrel (Citellus tridecemlineatus) showed that males that encountered al ready mated females tended not to mate with them. A prolongation of behavioral estrus after mating, which occurs in some induced ovulators, may lead to matings with additional males which, in turn, could lead to some sperm competition. In ferrets (219), voles (36), and cats (236), circulating progesterone levels do not rise until 3-4 days after mating which is when females' proceptivity and receptivity decline. In cats (236), repeated matings elicit a LH response only during the first 2 days of estrus even though estrus lasts 6 days on average. Taken together, these data suggest that there is probably very limited sperm competition in induced ovulating species. The absence of sperm competition may counterbalance the evolutionary advantage of synchronization of gamete availability that prevails in induced ovulating species. As a result, induced ovulation evolved in only a limited number of mammalian species.

\section{Ovarian Control of Female Sexual Receptivity}

Female reproduction requires a finely tuned coordination of the brain, pituitary, and ovaries to produce mature ova. The developing ovarian follicles secrete high levels of estradiol which act in the hypothalamus to promote the display of female sexual behavior, thereby ensuring that the female is maximally receptive to a male conspecific at the time that she is ready to ovulate. There is some species variability in the duration and periodicity of estrus among induced ovulators (Table 1). Caution is warranted in interpreting the data in Table 1 since information on estrus duration and the interval between mating and ovulation is still scarce for many induced ovulators. Most induced ovulating species show well-defined periods of behavioral estrus which last a few days. For instance, female cats remain receptive for an average of 6 days during which mating may occur repeatedly (237). By contrast, female ferrets will stay in estrus for up to several months or until mating occurs $(88,143$, 186).

The duration and occurrence of estrous periods are strongly influenced by environmental and social cues. Many mammals are seasonal breeders, with reproductive activity being controlled by seasonal changes in photoperiod. For instance, the ferret comes into estrus in response to lengthening days (22) which occur in early spring in the northern hemisphere. Males show testicular development at the same time. If mated, females become pregnant, deliver a litter approximately 41 days later, and nurse the litter for an additional 42 
TABLE 1

\section{List of Mammalian Species Showing Mating-Induced Ovulation (Adapted from 152)}

\begin{tabular}{|c|c|c|c|c|c|}
\hline Order & Species & Estrus characteristics & $\begin{array}{c}\text { Mating requirements } \\
\text { for ovulation }\end{array}$ & $\begin{array}{l}\text { Seasonal } \\
\text { breeder }\end{array}$ & $\begin{array}{l}\text { Interval } \\
\text { between } \\
\text { mating and } \\
\text { ovulation }\end{array}$ \\
\hline \multirow[t]{4}{*}{ Insectivora } & $\begin{array}{l}\text { Short-tailed Shrew } \\
\text { (Blarina } \\
\text { brevicauda) }\end{array}$ & $\begin{array}{l}\text { Estrus duration: up } \\
\text { to } 33 \text { days in the } \\
\text { absence of a male }\end{array}$ & $\begin{array}{l}\text { Multiple ejaculatory } \\
\text { series }\end{array}$ & Yes & $\begin{array}{l}\text { 55- } 71 \text { h (64 h } \\
\text { on } \\
\text { average) }\end{array}$ \\
\hline & $\begin{array}{l}\text { Least Shrew } \\
\text { (Cryptotis parva) }\end{array}$ & $\begin{array}{l}\text { Estrus duration: 1-2 } \\
\text { days }\end{array}$ & $\begin{array}{l}\text { Multiple ejaculatory } \\
\text { series for at least } \\
12-36 \mathrm{~h}\end{array}$ & No & $?$ \\
\hline & $\begin{array}{l}\text { White-toothed } \\
\text { Shrew } \\
\text { (Crocidura } \\
\text { russula } \\
\text { monacha) }\end{array}$ & $\begin{array}{l}\text { No ovarian estrous } \\
\text { cycles; receptive } \\
\text { throughout } \\
\text { pregnancy }\end{array}$ & $?$ & No & $15-17 \mathrm{~h}$ \\
\hline & $\begin{array}{l}\text { Asian Musk Shrew } \\
\text { (Suncus } \\
\text { murinus) }\end{array}$ & $\begin{array}{l}\text { No ovarian estrous } \\
\text { cycles; estrus is } \\
\text { induced by } \\
\text { exposure to males; } \\
\text { receptive } \\
\text { throughout } \\
\text { pregnancy }\end{array}$ & $\begin{array}{l}\text { Multiple ejaculatory } \\
\text { series for at least } \\
24 \mathrm{~h}\end{array}$ & Yes & $19 \mathrm{~h}$ \\
\hline \multirow[t]{10}{*}{ Rodentia } & $\begin{array}{l}\text { 13-lined ground } \\
\text { squirrel (Citellus } \\
\text { tridecemlineatus) }\end{array}$ & $\begin{array}{l}\text { Estrus duration: } 2-4 \\
\text { weeks, recurring at } \\
\text { 2-4 week intervals }\end{array}$ & $\begin{array}{l}\text { Single ejaculatory } \\
\text { series }\end{array}$ & Yes & $8-12$ h \\
\hline & $\begin{array}{l}\text { 5-striped Indian } \\
\text { palm squirrel } \\
\text { (Funambulus } \\
\text { pennanti) }\end{array}$ & $\begin{array}{l}\text { Estrus duration: } 1 \\
\text { day }\end{array}$ & $?$ & $\begin{array}{l}\text { Yes, } \\
\text { depending } \\
\text { on }{ }^{\circ} \mathrm{N}\end{array}$ & $24 \mathrm{~h}$ \\
\hline & $\begin{array}{l}\text { Short-tailed field } \\
\text { vole (Microtus } \\
\text { agrestis) }\end{array}$ & $\begin{array}{l}\text { Estrus duration: 1-5 } \\
\text { days; recurring at } \\
\text { irregular intervals }\end{array}$ & Single intromission & Yes & $9-12 \mathrm{~h}$ \\
\hline & $\begin{array}{l}\text { California mouse } \\
\text { (Microtus } \\
\text { californicus) }\end{array}$ & $?$ & $?$ & No & $<15 \mathrm{~h}$ \\
\hline & $\begin{array}{c}\text { Montane vole } \\
\text { (Microtus } \\
\text { montanus) }\end{array}$ & $?$ & $\begin{array}{l}\text { Single ejaculatory } \\
\text { series }\end{array}$ & Yes & $8-10 \mathrm{~h}$ \\
\hline & $\begin{array}{l}\text { Prairie vole } \\
\quad \text { (Microtus } \\
\text { ochrogaster) }\end{array}$ & $\begin{array}{r}\text { Estrus is induced by } \\
\text { exposure to males }\end{array}$ & $\begin{array}{l}\text { Multiple ejaculatory } \\
\text { series }\end{array}$ & No & $10-11 \mathrm{~h}$ \\
\hline & $\begin{array}{l}\text { Meadow vole } \\
\text { (Microtus } \\
\text { pennsylvanicus) }\end{array}$ & $?$ & $?$ & $\begin{array}{l}\text { Yes, } \\
\text { depending } \\
\text { on }{ }^{\circ} \mathrm{N}\end{array}$ & $?$ \\
\hline & $\begin{array}{l}\text { Pine vole (Microtus } \\
\text { pinetorum) }\end{array}$ & $?$ & $?$ & $?$ & $?$ \\
\hline & $\begin{array}{l}\text { Tree mouse } \\
\text { (Phenacomys } \\
\text { Iongicaudus) }\end{array}$ & $\begin{array}{l}\text { Estrus duration: up } \\
\text { to } 21 \text { days (average } \\
5.9 \text { days) }\end{array}$ & $?$ & Yes & $?$ \\
\hline & $\begin{array}{l}\text { Collared lemming } \\
\text { (Dicrostonyx } \\
\text { groenlandicus) }\end{array}$ & $\begin{array}{l}\text { Estrus duration: 2-22 } \\
\text { days }\end{array}$ & $?$ & No & 9-10 h \\
\hline \multirow[t]{2}{*}{ Lagomorpha } & $\begin{array}{l}\text { Hare (Lepus } \\
\text { europaeus) }\end{array}$ & $\begin{array}{l}\text { Estrus duration: up } \\
\text { to } 14 \text { days; } \\
\text { prepartum estrus }\end{array}$ & $\begin{array}{l}\text { Single ejaculatory } \\
\text { series }\end{array}$ & Yes & $<24 \mathrm{~h}$ \\
\hline & $\begin{array}{l}\text { Rabbit (Oryctolagus } \\
\text { cuniculus) }\end{array}$ & $\begin{array}{c}\text { Estrus duration: 2-15 } \\
\text { days; recurring at } \\
\text { 4-6 day intervals }\end{array}$ & $\begin{array}{l}\text { Single ejaculatory } \\
\text { series }\end{array}$ & No & $11-12 \mathrm{~h}$ \\
\hline
\end{tabular}


TABLE 1-Continued

\begin{tabular}{|c|c|c|c|c|c|}
\hline Order & Species & Estrus characteristics & $\begin{array}{l}\text { Mating requirements } \\
\text { for ovulation }\end{array}$ & $\begin{array}{c}\text { Seasonal } \\
\text { breeder }\end{array}$ & $\begin{array}{c}\text { Interval } \\
\text { between } \\
\text { mating } \\
\text { and } \\
\text { ovulation }\end{array}$ \\
\hline \multirow[t]{4}{*}{ Carnivora } & $\begin{array}{l}\text { Domestic cat (Felis } \\
\text { catus) }\end{array}$ & $\begin{array}{l}\text { Estrus duration: } 6 \\
\text { days on average }\end{array}$ & $\begin{array}{l}\text { Multiple ejaculatory } \\
\text { series }\end{array}$ & Yes & $24-54 \mathrm{~h}$ \\
\hline & $\begin{array}{l}\text { Ferret (Mustela } \\
\text { furo) }\end{array}$ & $\begin{array}{l}\text { Estrus duration: up } \\
\text { to } 17 \text { weeks }\end{array}$ & Single intromission & Yes & $30 \mathrm{~h}$ \\
\hline & $\begin{array}{l}\text { Mink (Mustela } \\
\text { vison) }\end{array}$ & $\begin{array}{l}\text { Estrus duration: up } \\
\text { to } 3-4 \text { weeks }\end{array}$ & Single intromission & Yes & $33-72 \mathrm{~h}$ \\
\hline & $\begin{array}{l}\text { Racoon (Procyon } \\
\text { lotor) }\end{array}$ & $\begin{array}{l}\text { Estrus duration: 2-3 } \\
\text { days }\end{array}$ & $\begin{array}{l}\text { Single ejaculatory } \\
\text { series }\end{array}$ & Yes & $?$ \\
\hline \multirow[t]{4}{*}{ Artiodactyla } & $\begin{array}{l}\text { Llama (Lama } \\
\text { glama) }\end{array}$ & $?$ & $?$ & Yes & $24-48 \mathrm{~h}$ \\
\hline & $\begin{array}{l}\text { Alpaca (Lama } \\
\text { pacos) }\end{array}$ & $\begin{array}{l}\text { Estrus duration: 4-36 } \\
\text { days }\end{array}$ & $?$ & Yes & \\
\hline & $\begin{array}{l}\text { Onehumped Camel } \\
\text { (Camelus } \\
\text { dromedarius) }\end{array}$ & $\begin{array}{l}\text { Estrus duration: 17- } \\
28 \text { days }\end{array}$ & $\begin{array}{l}\text { Single ejaculatory } \\
\text { series }\end{array}$ & Yes & $12-24 \mathrm{~h}$ \\
\hline & $\begin{array}{l}\text { Two-humped Camel } \\
\text { (Camelus } \\
\text { bactrianus) }\end{array}$ & $\begin{array}{l}\text { Estrus duration: } 1-7 \\
\text { days; recurring at } \\
10-20 \text { day } \\
\text { intervals }\end{array}$ & $?$ & No & $?$ \\
\hline
\end{tabular}

${ }^{\circ} \mathrm{N}$ : north latitude

days. After weaning their young, females usually come back into estrus and become pregnant again if mated. Generally, female ferrets will breed only twice a year. In some other induced ovulators social cues play an essential role in activating the reproductive axis. For example, in virgin female prairie voles, estrus is induced by exposure to an unfamiliar male (reviewed in 180). Pheromonal and tactile stimuli from a male caused significant increases in uterine weights (35) and circulating estradiol levels (44). As in voles, behavioral receptivity in musk shrews depends on the presence of a male $(63,185)$. Female musk shrews typically show no ovarian cycles. When she first encounters a male, the female shrew initially responds very aggressively for up to $1 \mathrm{~h}$. Eventually the female becomes sexually receptive and permits the male to copulate with her. Females continue to be receptive to males for several days (reviewed in 201). This response of behavioral receptivity toward the male is too rapid to be stimulated by ovarian estradiol production, because circulating estradiol levels are relatively low around the time of mating (75). Females' sexual behavior is probably stimulated by testosterone from adrenal origin, which acts in the hypothalamus after being aromatized to estradiol (182).

In induced ovulating species, estradiol is the sole endocrine stimulus acting in the brain to promote behavioral estrus. Administration of estradiol induced full behavioral receptivity in ovariectomized rabbits (18), ferrets (15), cats (231), prairie voles (59), collared lemmings (Dicrostonyx groenlandicus; 92), and brown lemmings (Lemmus trimucronatus; 102). Likewise, estradiol treat- 
ment to female musk shrews activated sexual behavior, though only when administered in supraphysiological doses (183). Testosterone appears to be more effective than estradiol in activating behavioral receptivity in ovariectomized musk shrews (182). There is no indication that progesterone is also needed for the induction of behavioral receptivity in induced ovulators that have been estrogen primed. Short-term (4- $8 \mathrm{~h}$ ) exposure to progesterone of ovariectomized females primed with low doses of estradiol did not affect behavioral receptivity in brown lemmings (102) or ferrets (13). Long-term ( $>24$ h) exposure to progesterone clearly inhibited female receptivity in these species $(13,102)$. Likewise, in the prairie vole $(59)$, administration of progesterone to estradiol-primed animals induced both short-term (within hours) and longterm inhibition of sexual responses. This contrasts with the situation in many spontaneous ovulators, such as rats (160), hamsters (53), guinea pigs (254), and goats (20), in which progesterone has both facilitatory and inhibitory effects on sexual receptivity depending on when it is administered.

Progesterone binding sites have been found in the preoptic area (POA), mediobasal hypothalamus (MBH), amygdala, anterior pituitary, and some cortical areas of ovariectomized femal eferrets (13). Their distribution resembles that previously reported for progesterone receptors in the rat $(138,157)$ and guinea pig $(23)$. As in numerous spontaneously ovulating species, including rats $(138,157)$, guinea pigs (23), hamsters (124), mice (187), and macaques (137), exposure to estradiol significantly enhanced the concentration of cytosolic progesterone binding sites in the hypothalamus and pituitary gland of ovariectomized female ferrets (13). In contrast to rats $(138,157)$ and guinea pigs $(23)$, estradiol treatment did not significantly augment progesterone binding sites in the ferret's POA. Likewise, in the prairie vole (45), in which estrus is induced by exposure to male-derived stimuli, progesterone receptor binding was augmented in the $\mathrm{MBH}$, but not the POA, when females were exposed to a male for $18 \mathrm{~h}$ followed by $30 \mathrm{~h}$ alone in the male's soiled cage. Thus, estradiol clearly stimulates synthesis of nuclear progesterone receptors in both induced and spontaneous ovulators. However, there are differential effects of progesterone on female sexual receptivity between induced and spontaneous ovulators. It should be noted, however, that the absence of a facilitatory effect of progesterone on female's sexual receptivity is not limited to induced ovulating species. For example, progesterone did not facilitatetheexpression of female sexual behavior in ovariectomized, estradiol-primed rhesus monkeys (14). Likewise, estradiol failed to stimulate the synthesis of cytosolic progesterone receptors in the POA of monkeys (137). Whether differences in the distribution of estrogen-induced progesterone receptors underlie this differential effect of progesterone on female sexual behavior in induced versus spontaneous ovulators remains questionable.

\section{GnRH CONTROL OF THE PREOVULATORY LH SURGE}

The decapeptide $\mathrm{GnRH}$ is the primary hypothalamic regulator of $\mathrm{LH}$ release in both spontaneous and induced ovulators. $\mathrm{GnRH}$, or $\mathrm{LH}-\mathrm{RH}$ as it was 
originally called, was discovered independently in the early 1960s by McCann, Taleisnik, and Friedman (144) and Campbell, Feuer, and Harris (see 90). Approximately 15 years later, groups headed by Guillemin (86) and Schally (199) established the amino acid sequence of the mammalian decapeptide $\mathrm{GnRH}(\mathrm{mGnRH})$. Recently, a second molecular form of GnRH has been identified in brains of several eutharian mammals, including humans (232), tree (113) and musk (54) shrews, and golden moles (118). This second molecular form has been identified as chicken II GnRH (cGnRH-II), which has also been found in many other nonmammalian vertebrate species (118, 159). Using immunocytochemical procedures, the neural distribution of $\mathrm{GnRH}$ producing neurons has been specified in numerous vertebrate species. Mammalian GnRH and $\mathrm{CGnRH}-\mathrm{II}$ producing neurons are concentrated in two separate anatomical locations. Neurons producing the mammalian form of $\mathrm{GnRH}$ are distributed in a loose rostral-caudal continuum in the ventral forebrain. There are clear species $(10,181,227)$ differences in the distribution of these GnRH neurons (Fig. 3); however, these differences are not correlated with individual species' status as spontaneous as opposed to induced ovulators. The principal projection of $\mathrm{mGnRH}$ neurons is to the median eminence, where terminals of these neurons have been observed in the pericapillary space of the hypophyseal portal plexus $(78,205)$. The mammalian form of $\mathrm{GnRH}$ is released from the median eminence in a pulsatile fashion (e.g., 30, 68). Neurons expressing cGnRH-II reside in the midbrain $(54,113,118,232)$. The major terminal field for these cGnRH-II neurons is the medial habenula, and in contrast to forebrain $\mathrm{mGnRH}$ fibers, few $\mathrm{cGnRH}$-II fibers are visible in the median eminence (54). The fact that $\mathrm{CGnRH}-\mathrm{II}$ has been conserved in species that have diverged evolutionarily suggests that it may have an important function. Several studies $(76,129,147,253)$ have shown that $\mathrm{cGnRH}-\mathrm{II}$ is effective in releasing $\mathrm{LH}$ and FSH from the mammalian pituitary. However, $\mathrm{mGnRH}$ is a much more potent stimulator of pituitary gonadotropin secretion $(76,147)$. Also, in contrast to $\mathrm{mGNRH}$, intracerebroventricular infusion of $\mathrm{cGnRH}-\mathrm{II}$ had no effect on female sexual behavior in musk shrews (200). More research is needed to specify the function of this second form of GnRH in the mammalian brain. Henceforth in this review we will only discuss the neuroendocrine mechanisms controlling synthesis and release of mammalian $\mathrm{GnRH}$ in the forebrain of induced ovulators.

\section{GnRH Secretion}

The introduction of push-pull perfusion (PPP) and microdialysis techniques to measure in vivo release of hypothalamic neuropeptides in conscious, freely moving animals enabled investigators to measure $\mathrm{GnRH}$ secretion into the hypophyseal portal system. To date, the rabbit is the only induced ovulating species in which these techniques have been used. Groups headed by Ramirez (177) and Spies (169) showed independently that the in vivo release of GnRH is pulsatile in the rabbit. The pulsatile pattern of tonic $\mathrm{GnRH}$ release in the 


\section{Musk Shrew}



\section{Rabbit}

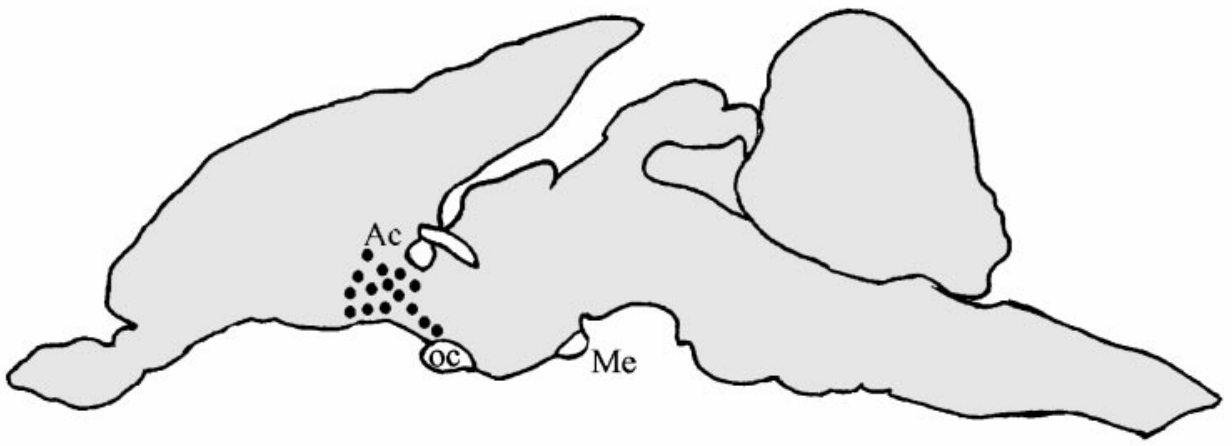

\section{Ferret}



FIG. 3. The distribution of neurons (๑) immunoreactive for mammalian GnRH in sagittal views of the brains of the musk shrew, rabbit, and ferret. The number of dots does not represent the actual number of GnRH neurons present in each species. The brains are not drawn to scale. Ac, anterior commissure; oc, optic chiasm; on, optic nerve; Me, median eminence.

rabbit resembles that seen in spontaneous ovulators such as the rat (131), the monkey (132), and the sheep (130). Both research groups $(114,136)$ have also shown that the receipt of intromissions induced a rapid increase in hypotha- 


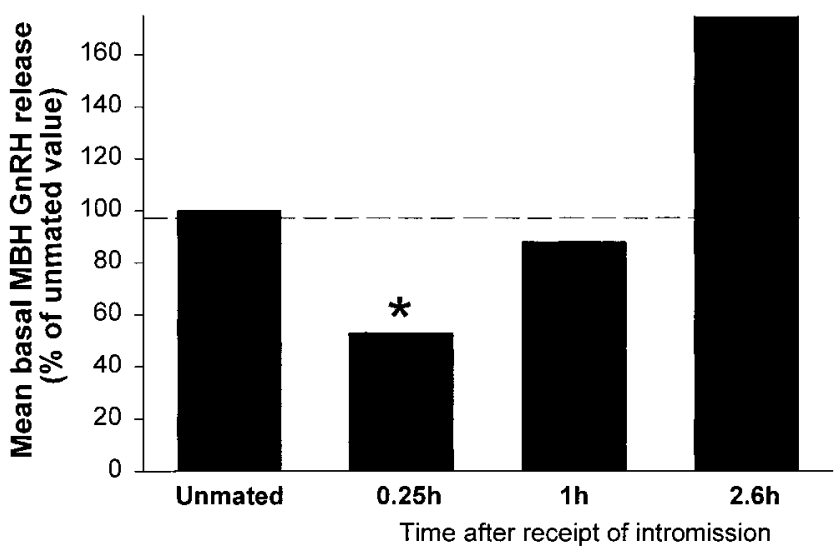

Adapted from Lambert et al. (Physiol Behav 1992; 52: 809-813)

FIG. 4. Mean basal in vitro release of GnRH was significantly decreased in mediobasal hypothalamic tissue of estrous female ferrets killed $0.25 \mathrm{~h}$ after the onset of intromission compared to unmated estrous females. The in vitro rel ease of $\mathrm{GnRH}$ had recovered in females killed 1 or $2.6 \mathrm{~h}$ after the onset of intromission. Data are expressed as percentage of unmated value. $* \mathrm{P}<0.05$ compared to unmated value.

Iamic GnRH release. The magnitude of this mating-induced output of GnRH was far greater ( $\sim 50-100$-fold) than what has been reported for other species, including rats (191) and sheep (43), on proestrus.

In ferrets (121), mating-induced changes in GnRH release from hypothalamic slices were assessed by in vitro perifusion. Perifusion chambers contained individual slices from the $\mathrm{MBH}$ which were collected from female ferrets that had been either mated or left unpaired. The in vitro release as well as the content of $\mathrm{GnRH}$ in $\mathrm{MBH}$ slices were significantly lower in estrous females killed $0.25 \mathrm{~h}$ after receipt of an intromission than in unmated estrous females and in estrous females killed 1 or $2.6 \mathrm{~h}$ after the onset of mating (121; Fig. 4). This suggests that the receipt of an intromission induces a release of $\mathrm{GnRH}$ from the female's MBH which quickly depletes neuronal terminals of the peptide. Additional, independent evidence (19) of an immediate release of $\mathrm{GnRH}$ following mating in the ferret is that fewer $\mathrm{GnRH}$-immunoreactive (IR) perikarya were detected in the $\mathrm{MBH}$ of ovariectomized, estradiol-primed female ferrets killed 20 min after receiving mechanical vaginal-cervical stimuIation. In the vole (218), a similar drop in GnRH content was found in dissected hypothalami of females killed 5 min after mating. Taken together, these results suggest that the mating-induced preovulatory LH surge is stimulated by an immediate release of $\mathrm{GnRH}$ from the $\mathrm{MBH}$ in rabbit, vole, and ferret. In contrast to these induced ovulating species, a single mating bout, which typically includes about 20 mounts with and without intromission terminating in 1 ejaculation, initially increased GnRH-IR cell numbers and content in the POA and other forebrain areas of female musk shrews (55). Within 24- $40 \mathrm{~h}$ after receipt of an ejaculation, females that ovulated had fewer GnRH-IR 
neurons and lower GnRH content in the entire brain than females that did not ovulate. Unfortunately, the exact time of the preovulatory LH surge could not be determined since there is no shrew LH assay available (55). However, the drop in forebrain GnRH content presumably reflects its release from the median eminence. These results imply that the female musk shrew represents a special case of induced ovulation in which receipt of intromissive stimulation does not lead to a rapid release of $\mathrm{GnRH}$ and an immediate preovulatory surge in LH.

\section{Neuronal Fos/GnRH Colocalization}

The expression of immediate early genes, such as c-fos and c-jun, has been used as a marker of neural activation in many neuroendocrine systems, including GnRH neurons (99). Dual-label immunocytochemical visualization of F os and GnRH protein has been used in both ferrets $(122,227)$ and rabbits (28) to specify the population of $\mathrm{GnRH}$ neurons which is activated by matingassociated stimuli leading to a preovulatory LH surge. In the ferret (122), receipt of an intromission significantly increased the percentage of $\mathrm{GnRH}$ neurons expressing Fos protein in the $\mathrm{MBH}$ of estrous females killed $1 \mathrm{~h}$ after the onset of a 5-min intromission. However, the percentage of Fos- or J unexpressing $\mathrm{GnRH}$ neurons returned to basal levels $3 \mathrm{~h}$ after onset of intromission (227; Fig. 5), even though the preovulatory LH surge lasts for at least $12 \mathrm{~h}$ in this species (33). It therefore seems unlikely that immediate early gene products such as Fos or J un that are formed in GnRH neurons play a critical role in the termination of the LH surge since they disappear long before the surge is completed. Fos and J un are also probably not involved in the initiation of the preovulatory LH surge since the percentage of F os-IR GnRH neurons did not rise until 1-1.5 $\mathrm{h}$ after mating (227; Fig. 5). This is long after the initial release of $\mathrm{GnRH}$, which occurs within 15 min of mating (121). It is possible that Fos, perhaps by increasing GnRH gene transcription $(60,99)$, plays a role in replenishing intracellular MBH GnRH stores with the decapeptide within the first hour after the onset of intromission (121).

At the time of the steroid-induced preovulatory LH surge, a similar induction of Fos protein within GnRH neurons has been observed in spontaneously ovulating species, including mice (245), rats (125), hamsters (17, 60), and sheep (155). Interestingly, artificial vaginal-cervical stimulation was successful in inducing Fos protein in GnRH neurons of the female rat even in the absence of circulating steroids (172). Rajendren et al . (176) demonstrated that repeated mating induced Fos protein in GnRH neurons of ovariectomized, estradiol-treated female rats. Moreover, Wu et al. (245) reported that mating augmented the percentage of Fos-IR GnRH neurons induced by the administration of estradiol and progesterone and extended this period of enhanced colocalization in female mice. These results suggest that the neural pathways by which sensory stimuli associated with mating reach and activate for ebrain $\mathrm{GnRH}$ neurons in induced ovulators are also present in the rat and mouse. 
A


B

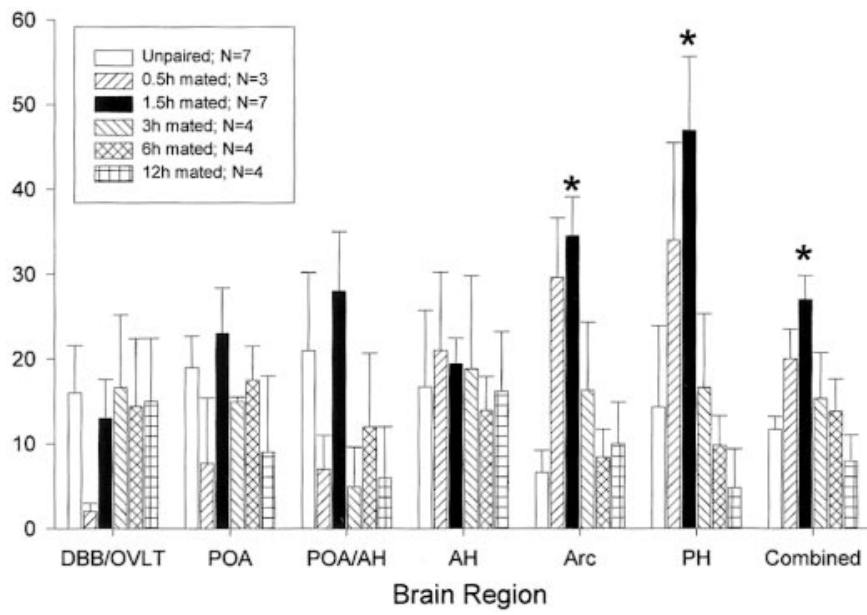

FIG. 5. Activation of mediobasal hypothalamic $G n R H$ neurons by mating-associated stimuli in estrous female ferrets. (A) Photomicrograph showing a single-labeled (top) and a double-labeled (bottom) GnRH-immunoreactive (IR) neuron with Fos protein in the nucleus. Arrows indicate GnRH-IR cytoplasm; arrowheads indicate the nucleus. (B) Mean percentage ( \pm SEM) of GnRH-IR neurons colabeled with Fos-IR at the level of the diagonal band of broca/organum vasculosum of the lamina terminalis (DBB/OVLT), the preoptic area (POA), the border of the preoptic area/ anterior hypothalamus (POA/AH), the anterior hypothalamus $(\mathrm{AH})$, the arcuate nucleus $(\operatorname{Arc})$, the posterior hypothalamus $(\mathrm{PH})$, and all these brain regions combined. Groups included unpaired and mated estrous female ferrets killed $0.5,1.5,3.0,6.0$, or $12.0 \mathrm{~h}$ after receipt of one 5-min intromission. *P $<0.05$ compared to the unpaired group. Adapted from 227.

\section{GnRH Biosynthesis}

There is increasing evidence that the amount of GnRH peptide available for secretion into the portal circulation is regulated by a combination of transcriptional and posttranscriptional events. These include the rate of transcription of the proGnRH gene, polyadenylation and 5' capping of the resulting RNA, processing of the GnRH primary transcript into mRNA, transport of the mRNA to the cytoplasm, translation rate of the mRNA into pre-pro-GnRH peptide, and processing of the precursor into GnRH decapeptide (83). To date the ferret (8) is the only induced ovulator in which MBH GnRH mRNA levels have been assessed in relation to mating-induced preovulatory LH surges. The receipt of intromissive stimulation by estrous ferrets stimulated $\mathrm{GnRH}$ release from the $\mathrm{MBH}$ that initially depleted stores of the peptide (121; Fig. 4). However, MBH GnRH stores were replenished within $1 \mathrm{~h}$ after the onset of intromission, suggesting that the preovulatory $\mathrm{GnRH}$ surge in the ferret may be associated with an increase in $\mathrm{GnRH}$ biosynthesis. Bakker et al. (8) compared MBH GnRH mRNA levels among groups of estrous ferrets killed at different times during the mating-induced preovulatory LH surge. GnRH mRNA levels in the MBH were assessed by means of in situ hybridization using a ${ }^{35} \mathrm{~S}$-labeled synthetic oligoprobe complementary to the $\mathrm{GnRH}$ coding region (bases 102-149) of the human CDNA (2). No evidence of increased $\mathrm{MBH}$ 


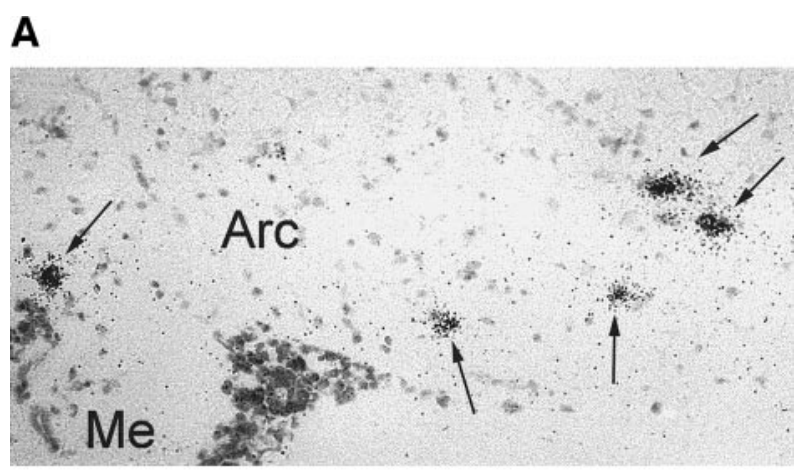

B

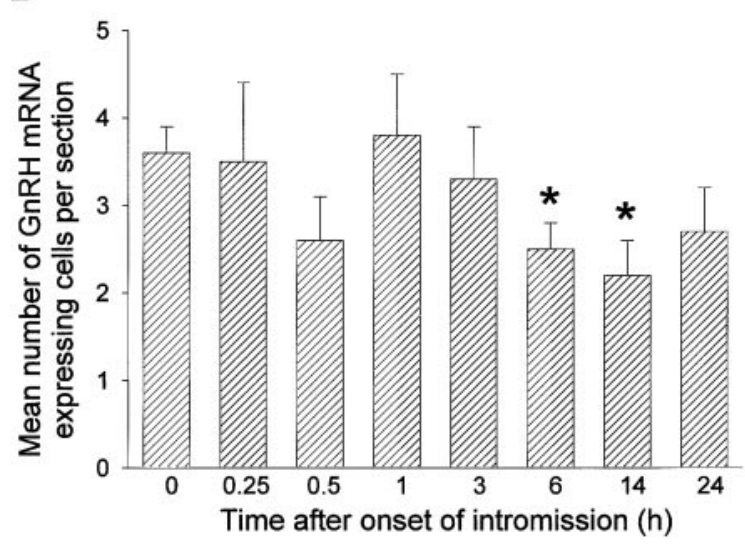

FIG. 6. Effect of receipt of an intromission on mediobasal hypothalamic GnRH mRNA levels in estrous female ferrets. (A) Photomicrograph of cells expressing GnRH mRNA in the arcuate region (Arc) and the median eminence (Me) of an unmated estrous female ferret. Arrows indicate labeled cells. (B) Mean ( \pm SEM) number of GnRH mRNA-expressing cells in the arcuate region of estrous female ferrets. $* P<0.05$ compared with unmated $(0-h)$ estrous females. Adapted from 8.

GnRH mRNA levels was found during the ferret's mating-induced preovulatory LH surge (8; Fig. 6). Instead, the number of GnRH mRNA-containing cells dropped significantly in the arcuate region beginning $6 \mathrm{~h}$ after onset of intromission and remained low thereafter. This decrease probably reflected a reduction in cellular GnRH mRNA content so that cells expressing decreased levels of mRNA were no longer detected with the in situ hybridization method used. Indeed, cellular levels of GnRH mRNA in the arcuate region decreased significantly in estrous females killed $14 \mathrm{~h}$ after the onset of intromission.

The absence of any increases in GnRH mRNA levels during the matinginduced preovulatory LH surge suggests that posttranscriptional events, such as increased translation of $\mathrm{GnRH}$ mRNA, increased conversion of precursor into mature $\mathrm{GnRH}$ peptide, and/or increased transport of $\mathrm{GnRH}$ peptide to the nerve terminals, contribute to the previously (121) observed postcoital replenishment of $\mathrm{GnRH}$ stores in the ferret's MBH. There is additional, independent 
evidence (19) that MBH GnRH biosynthesis is regulated by posttranscriptional mechanisms in the ferret. The number of protein-synthesizing organelles, particularly Golgi complexes, was significantly increased in GnRH neurons of female ferrets that received vaginal-cervical stimulation.

Numerous studies (reviewed in 83, 190) have been conducted in spontaneously ovulating species, including rats and sheep, to determine whether the steroid-induced preovulatory release of $\mathrm{GnRH}$ depends, in part, on increased GnRH gene transcription in POA neurons. Unfortunately, results obtained in these studies have been inconclusive. In the rat, cellular GnRH mRNA levels and/or GnRH mRNA cell numbers have been reported to increase in the organum vasculosum of the lamina terminalis (OVLT)/rostral POA either around the time of $(164,252)$ or preceding $(82,174)$ the preovulatory LH surge. By contrast, in other studies $(74,139)$ no changes in POA GnRH mRNA levels were seen across the rat's estrous cycle. In the ewe $(58,91) \mathrm{GnRH}$ mRNA levels have been reported to decrease in the POA at the time of the preovulatory $\mathrm{LH}$ surge. The finding in ferrets (8) that the mating-induced preovulatory $\mathrm{LH}$ surge is accompanied by progressively decreasing levels of MBH GnRH mRNA is comparable to those earlier findings in the sheep $(58,91)$. However, the temporal relationship between the changes observed in POA or $\mathrm{MBH} G \mathrm{GRH}$ mRNA levels and $L H$ release differs between ferrets and sheep. In the ferret (8), MBH GnRH mRNA levels started to decrease during the peak phase of the LH surge and remained low until its end, whereas in the sheep (91) GnRH mRNA levels decreased in the POA before the onset of the LH surge. This difference points once again to the existence of different neuroendocrine mechanisms controlling the preovulatory release of $\mathrm{GnRH}$, and consequently $\mathrm{LH}$, in induced and spontaneously ovulating species.

\section{Sex Differences in GnRH Secretion}

The ability to generate preovulatory LH surges is sexually dimorphic in induced ovulators as in numerous spontaneously ovulating species (Fig. 7). Mating induced LH surges in female, but not in male, voles (84), ferrets (32), and rabbits $(105,247)$. In male ferrets (32) LH secretion was actually reduced significantly after an intromission was achieved with a female. Such sex dimorphisms in mating-induced (and spontaneous) LH secretion probably originate from sex differences in the neural inputs to $\mathrm{GnRH}$ neurons since the anterior pituitary is not sexually differentiated $(12,32)$. Gonadectomized male and female ferrets (32) showed similar LH responses to exogenous GnRH treatment, regardless of whether they were tested with or without concurrent estradiol treatment. More recently, Yang et al. (247) provided direct evidence for the absence of a coitus-induced surge in $\mathrm{MBH}$ release of $\mathrm{GnRH}$ as well as in plasma $\mathrm{LH}$ in the male rabbit.

Among spontaneously ovulating species, sex dimorphisms in the occurrence of preovulatory LH secretion have been studied most extensively in the laboratory rat $(89,161,173)$. A preovulatory LH surge could be induced in female, 


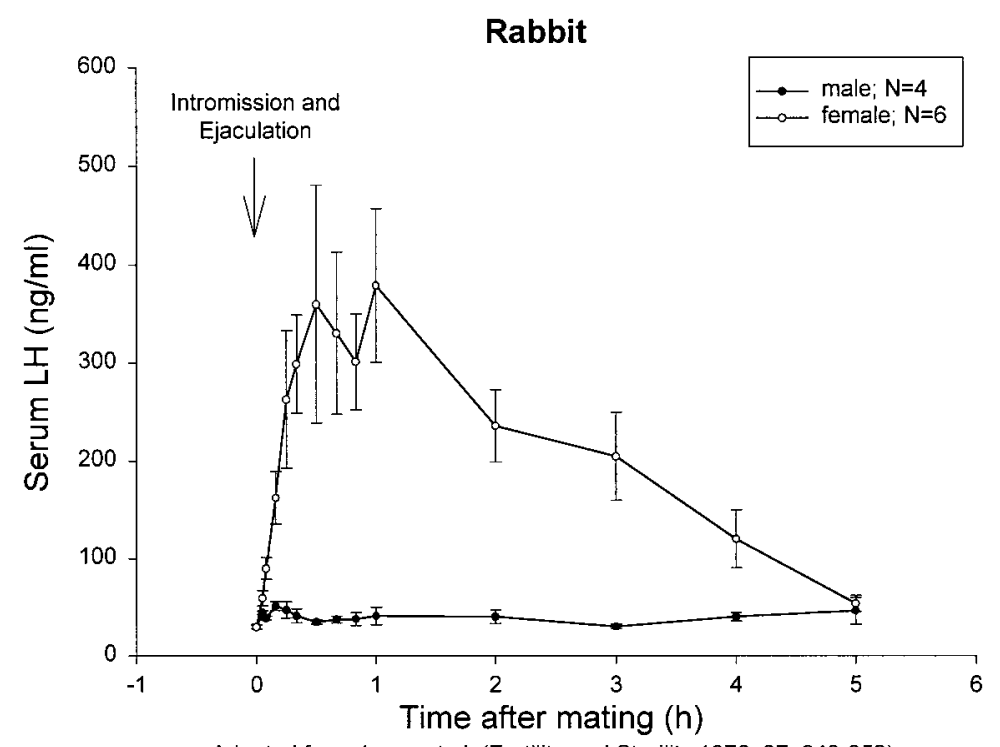

Adapted from Jones et al. (Fertility and Sterility 1976; 27: 848-852).



Adapted from Carroll et al. (Endocrinology 1987; 121: 1349-1359)

FIG. 7. Sexual dimorphism in mating-induced LH secretion in the rabbit and ferret. For the rabbit, data represent means \pm SEM; for the ferret, individual profiles of LH release following mating in a representative male and female tested while in breeding condition.

but not in male, rats following gonadectomy and administration of estradiol (161). The sexual differentiation of the GnRH-LH surge system depends on the perinatal actions of testosterone and/or its estrogenic metabolite on the 
male rat's hypothalamus $(161,220,226)$. However, the site and mechanism by which testosterone acts to masculinize the neuroendocrine circuitry controlling GnRH release in males is unclear. Using both immunocytochemical (122) and in situ hybridization procedures (7), no sex differences were found in the number, anatomical distribution, or morphology of $\mathrm{GnRH}$ neurons in the ferret, as in numerous spontaneously ovulating species $(241,242,243)$. By contrast, in the musk shrew (184), males had significantly more GnRH-IR (of both mammalian and chicken-II forms) cells in the forebrain (medial septum, diagonal band of broca, POA, hypothalamus) and midbrain than females. Ovariectomy eliminated this sex difference, suggesting that sex differences in circulating gonadal steroids in adulthood are responsible for this sex dimorphism. As such, these variations in GnRH cell numbers do not represent actual sex difference in the total number of $\mathrm{GnRH}$-producing neurons in the musk shrew brain (184). Thus the sex dimorphism in the ability of mating or ovarian steroids to stimulate a preovulatory LH surge does not appear to result from sex differences in the number or distribution of GnRH neurons per se. Instead, this sex dimorphism probably reflects differences in the input circuits to forebrain GnRH neurons. Indeed, mating with intromission induced nuclear Fos-IR in MBH GnRH neurons in estrous female, but not male ferrets (122, 228) and rabbits (28). The distribution of mating-induced F os-I R in non-GnRH forebrain neurons was also sexually dimorphic in the ferret: Fos expression was significantly higher in the POA, bed nucleus of the stria terminalis (BNST), and ventrolateral hypothalamus (VLH) of estrous females compared to breeding males (228). These results point to sex differences in the processing of sensory inputs to the ferret's $\mathrm{MBH}$, including the $\mathrm{GnRH}$ neurons located in this region.

\section{REGULATION OF GRRH SECRETION AND BIOSYNTHESIS BY OVARIAN STEROID HORMONES}

As explained earlier, estradiol but not progesterone is required for the induction of behavioral receptivity in induced ovulators (e.g., 13, 102). However, it is unclear to what extent estradiol and/or progesterone act directly on the neural mechanisms controlling $\mathrm{GnRH}$ biosynthesis and release leading to a mating-induced preovulatory LH surge. Presumably, there is no direct action of estradiol or progesterone on GnRH neurons in induced ovulators (222) since these neurons lack nuclear estrogen or progesterone receptors (95, 126, 203, $210,224)$. There is recent evidence (206) of estrogen receptor $\alpha$ and $\beta$ mRNA expression by POA GnRH neurons that clearly fluctuated over the rat's estrous cycle, suggesting a possible direct action of estradiol on GnRH function. However, many researchers have looked for estrogen receptor protein in $\mathrm{GnRH}$ neurons without success (e.g., 95, 126, 203, 210, 224). Until more evidence is forthcoming, we are going to presume that $\mathrm{GnRH}$ neurons do not express estrogen receptors. 
Induced ovulators generally do not show spontaneous LH surges during their reproductive cycles, suggesting that the positive feedback actions of steroid hormones on $\mathrm{GnRH}$ release are reduced or absent in these animals. Likewise, there is little indication that administration of estradiol with or without progesterone induces preovulatory $\mathrm{LH}$ secretion in induced ovulators (e.g., 12, 13, 102, 149, 150, 197). In addition, there is no clear evidence that progesterone has any positive feedback actions on LH release in induced ovulators. In rabbits (96) progesterone and $20 \alpha$-hydroxyprogesterone ( $20 \alpha$ $\mathrm{OHP}$ ) levels increase significantly in the course of the preovulatory $\mathrm{LH}$ surge, whereas in ferrets (219), voles (36), and cats (236) progesterone levels do not start to rise significantly until 3-5 days after mating. Whether progesterone or $20 \alpha$-OHP facilitates the postcoital release of LH in the rabbit is still unclear $(80,97,179)$. I nfusion of pulses of progester one directly into the hypothalamus stimulated the release of GnRH in young, intact female rabbits (177). However, no such effect was observed when progesterone was infused continuously (134). Likewise, pulses of $20 \alpha-\mathrm{OHP}$ infused directly in the hypothalamus stimulated the release of $\mathrm{GnRH}$ in young, intact rabbits (135). This result supports the hypothesis of Hilliard et al. (97) that $20 \alpha$-OHP exerts positive feedback effects on the hypothalamus and pituitary by prolonging the postcoital output of LH from the pituitary. However, Goodman and Neill (80) did not observe any contribution of $20 \alpha-\mathrm{OHP}$ to $\mathrm{LH}$ release. In fact, female rabbits that were ovariectomized within $15 \mathrm{~min}$ after receipt of an ejaculation showed the same pattern of $\mathrm{LH}$ rel ease as intact rabbits, suggesting that the ovaries do not contribute to the preovulatory LH surge. Furthermore, subcutaneous administration of $20 \alpha-\mathrm{OHP}$ by silastic capsules actually attenuated $\mathrm{MBH}$ $\mathrm{GnRH}$ release without affecting LH or FSH release in ovariectomized female rabbits treated concurrently with either estradiol or no hormone (169).

A monosynaptic pathway between the suprachiasmatic nuclei (SCN), the circadian pacemaker, and GnRH neurons located in the rat's OVLT/POA is likely part of the neural circuit which mediates the stimulatory actions of ovarian steroids on GnRH release (217). In rats, the preovulatory LH surge occurs at a fixed circadian time that is synchronized by the prevailing lightdark cycle. For instance, in female rats (reviewed in 108) maintained on 14-h light and 10-h darkness (lights on between 05:00 and 19:00 h) the preovulatory LH surge typically occurs on the day of proestrus between 14:00 and 16:00 $\mathrm{h}$. It is unclear to what extent this timing of the LH surge to the light/dark cycle can be applied to other spontaneously ovulating species. In the rhesus monkey (112), for example, the estradiol-induced preovulatory LH surge does not appear to be coupled to the light/dark cycle. By contrast, in humans (65), the preovulatory LH surge usually occurs in the morning around 9:00 h. Destruction of the $\operatorname{SCN}(5,27)$ or exposure to constant illumination $(225)$ leads to a cessation of ovarian cyclicity and induces a state of persistent estrus in female rats. These animals will show coitus- but not steroid-induced ovulation. Thus, a spontaneous ovulator, such as the rat, can be transformed into an induced ovulator by ablation of the SCN-GnRH neural pathway. This finding raises the possibility that the SCN-GnRH pathway is either absent or weakly orga- 


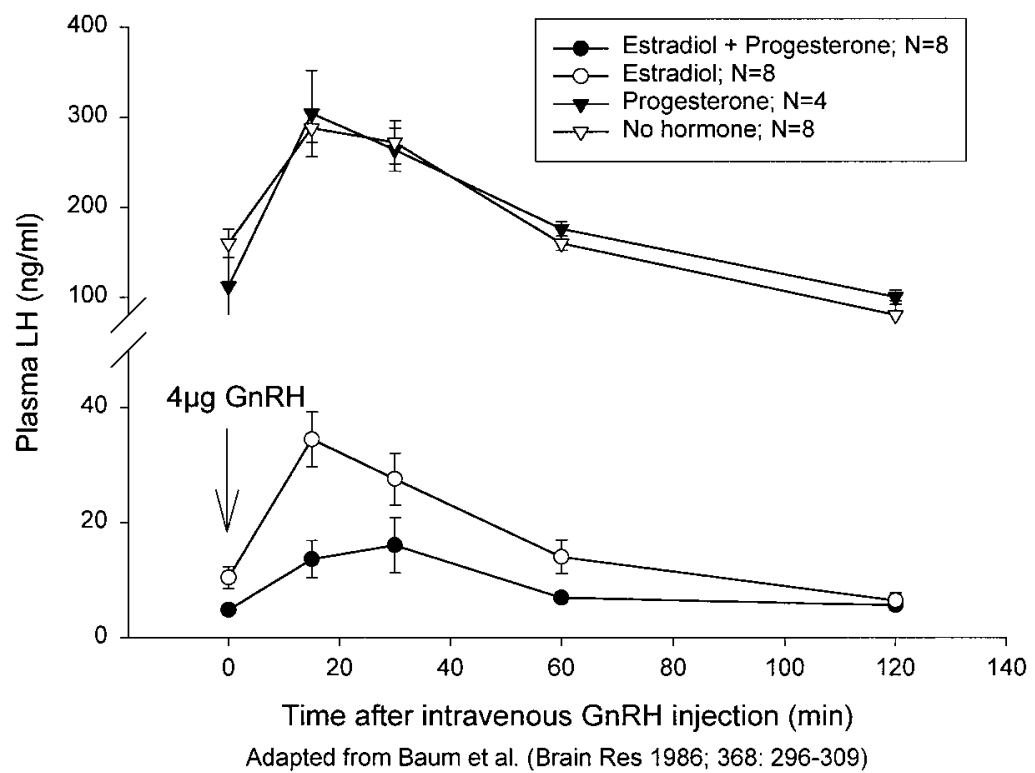

FIG. 8. Effect of chronic exposure of ovariectomized female ferrets to subcutaneous silastic capsules containing progesterone, estradiol, or no hormone on the stimulation of LH secretion by intravenous injection of $\mathrm{GnRH}$. Data are represented as means $\pm \mathrm{SEM}$.

nized in induced ovulators. In fact, ferrets show very weak circadian rhythms in locomotor activity levels (209) and in the display of maternal behavior (11).

Numerous studies $(31,106,156,169)$ suggest that ovarian steroids exert primarily negative feedback actions on hypothalamic $\mathrm{GnRH}$ release and pituitary LH secretion in induced ovulators. Removal of the ovaries caused a rapid increase in pituitary LH secretion in rabbits (169), cats (106), ferrets (31), and voles (156). Conversely, administration of estradiol following ovariectomy suppressed plasma LH levels to those found in intact rabbits (169), cats (106), and ferrets (31). The few data $(121,169)$ that are available on $\mathrm{GnRH}$ release after gonadectomy point to species differences among induced ovulators, as have been reported for spontaneously ovulating species $(29,110,111)$. In the female rabbit (169), ovariectomy enhanced pulsatile release of $\mathrm{GnRH}$ in the arcuate median eminence as measured by push-pull perfusion. By contrast, ovariectomy of estrous female ferrets (121) caused a decrease in the in vitro release and content of $\mathrm{GnRH}$ peptide in the $\mathrm{MBH}$.

There is no indication that progesterone exerts negative feedback effects on $\mathrm{LH}$ release in induced ovulators. Plasma progesterone levels are very low in both unmated estrous rabbits (179) and ferrets (219). F urthermore, ovariectomized female ferrets which received either progesterone or no hormone had similar plasma LH levels which were significantly higher than those of ovariectomized, estrogen-primed female ferrets (13). In the ferret, the ability of a single intravenous injection of $\mathrm{GnRH}$ to stimulate $\mathrm{LH}$ release was significantly lower in ovariectomized female ferrets implanted subcutaneously with silastic 
capsules containing estradiol and progesterone than in ferrets given only estradiol (Fig. 8; 13). Administration of progesterone alone to ovariectomized females did not affect the ability of exogenous $\mathrm{GnRH}$ to stimulate $\mathrm{LH}$ release. The finding that the inhibitory action of progesterone on pituitary responsiveness to GnRH depends on concomitant exposure to estradiol is correlated with the finding that estradiol doubled cytosolic progesterone receptor concentrations in the pituitary gland of ovariectomized ferrets (13). Donovan et al. (62) reported that plasma concentrations of progesterone dropped significantly in anestrous ferrets shortly after they were switched to a long-day photoperiod. Progesterone levels remained low during the subsequent period of 4-5 weeks prior to the onset of estrus. Ryan (188) observed episodic bursts of LH secretion during this same period prior to first estrus onset in female ferrets. These results raise the possibility that a reduction in the feedback effect of progesterone on GnRH neurons or pituitary gonadotropes contributes to the onset of estrus in this induced ovulator.

\section{GnRH Biosynthesis}

The in vitro release as well as the content of $\mathrm{GnRH}$ in $\mathrm{MBH}$ slices were reduced by ovariectomy of female but were not affected by castration of breeding male ferrets (121). By contrast, the time course of the rise in pulsatile LH secretion following estradiol withdrawal was very similar in gonadectomized male and female ferrets (31). These latter findings suggest that gonadal steroids exert strong negative feedback actions on LH secretion in ferrets of both sexes. However, GnRH release and perhaps also $\mathrm{GnRH}$ biosynthesis may be differentially regulated by gonadal steroids in male and female ferrets. It was therefore of interest to compare the effects of gonadectomy and steroid replacement on $\mathrm{MBH}$ GnRH mRNA cell number and content in ferrets of both sexes (7). Isotopic in situ hybridization showed that the number of $\mathrm{MBH}$ neurons and the cellular content of GnRH mRNA were equivalent among groups of gonadally intact ferrets in breeding condition as well as in gonadectomized steroid-treated and gonadectomized oil vehicle-injected ferrets of both sexes (7). This finding that castration of male ferrets had no effect on $\mathrm{MBH}$ GnRH mRNA cell number agrees with an earlier study by Tang et al. (211). Thus, the postgonadectomy rise in plasma LH levels, which is equivalent in the two sexes, does not depend on increased MBH GnRH gene transcription leading to increased GnRH mRNA levels. In addition, gonadal steroid hormones do not appear to modulate MBH GnRH mRNA levels in the ferret (7, 211). These data agree with results for the rat $(66,115,139,235)$, which also failed to detect any significant changes in hypothalamic GnRH mRNA levels after steroidal manipulations. By contrast, there are also numerous reports (reviewed in 83, 190) showing either increases or decreases in POA GnRH mRNA levels after gonadectomy in rats, although these changes in $\mathrm{GnRH}$ mRNA levels are relatively small compared to the amount of $\mathrm{LH}$ released following gonadectomy. Thus, the postgonadectomy rise in LH does not seem to 
depend on dramatic increases in hypothalamic GnRH gene transcription in either rats or ferrets. Instead, increased LH secretion following gonadectomy may result from an increase in the sensitivity of pituitary gonadotropes to lower amplitude GnRH pulses from the median eminence (110, 121). By contrast, in the rabbit (169), the postgonadectomy rise in LH is associated with an enhanced secretion of $\mathrm{GnRH}$ from $\mathrm{MBH}$ nerve terminals. This increase in $\mathrm{GnRH}$ release could be the result of increases in $\mathrm{GnRH}$ gene transcription and/or GnRH mRNA translation, suggesting that different neuroendocrine mechanisms underlie the postgonadectomy rise in $\mathrm{LH}$ secretion in rabbits as opposed to ferrets.

\section{NEUROTRANSMITTERS AND NEUROPEPTIDES INVOLVED IN THE PREOVULATORY ACTIVATION OF GRRH NEURONS}

The neural pathways via which sensory stimuli associated with mating reach and activate forebrain $\mathrm{GnRH}$ neurons in induced ovulators are still poorly understood. GnRH neurons lack estrogen as well as progesterone receptors in both spontaneous and induced ovulators, implying that these steroid hormones act on GnRH neurons via interneurons (reviewed in 94). Therefore, much of the work within the field of GnRH neurobiology has centered on components of the neural circuits that convey steroidal signals and/or sensory inputs to forebrain GnRH neurons. Pharmacological manipulation of various neurotransmitter and peptidergic systems has been shown to affect $\mathrm{GnRH}$ and subsequent $\mathrm{LH}$ release in female mammals. Most of this work has been done in spontaneous ovulators, including rats $(9,25,93,133,153)$ and monkeys (reviewed in 208). To date, the rabbit (reviewed in 179, 208) and ferret (120, 229) are the only induced ovulating species in which pharmacological studies have been conducted to analyze the neuroendocrine signals which control the postcoital release of $\mathrm{GnRH}$ from the $\mathrm{MBH}$. Norepinephrine, neuropeptide $\mathrm{Y}$, and opioid peptides are the best studied neurotransmitter/neuropeptides in this context.

\section{Norepinephrine}

Much evidence suggests that the catecholamine norepinephrine (NE) facilitates GnRH release in the estrous female rabbit's MBH: (1) intravenous administration of dibenamine, an $\alpha$-adrenergic antagonist blocked coitus-induced ovulation (198); (2) intracerebroventricular administration of NE stimulated GnRH secretion (170, 178, 195); (3) mating induced an immediate and substantial increase in $\mathrm{MBH}$ NE several minutes prior to the initiation of the preovulatory GnRH surge (Fig. 9; 247), whereas prazosin, an $\alpha_{1}$-adrenergic receptor blocker administered either in the arcuate region median eminence or into the third ventricle, attenuated the mating-induced GnRH surge (246); and (5) desipramine (DMI), a specific NE transporter (NET) protein blocker ad- 


\section{Mated Female Rabbits \\ $(\mathrm{N}=4)$}


Time before and after mating $(h)$



\section{Mated Male Rabbits}

$(\mathrm{N}=6)$
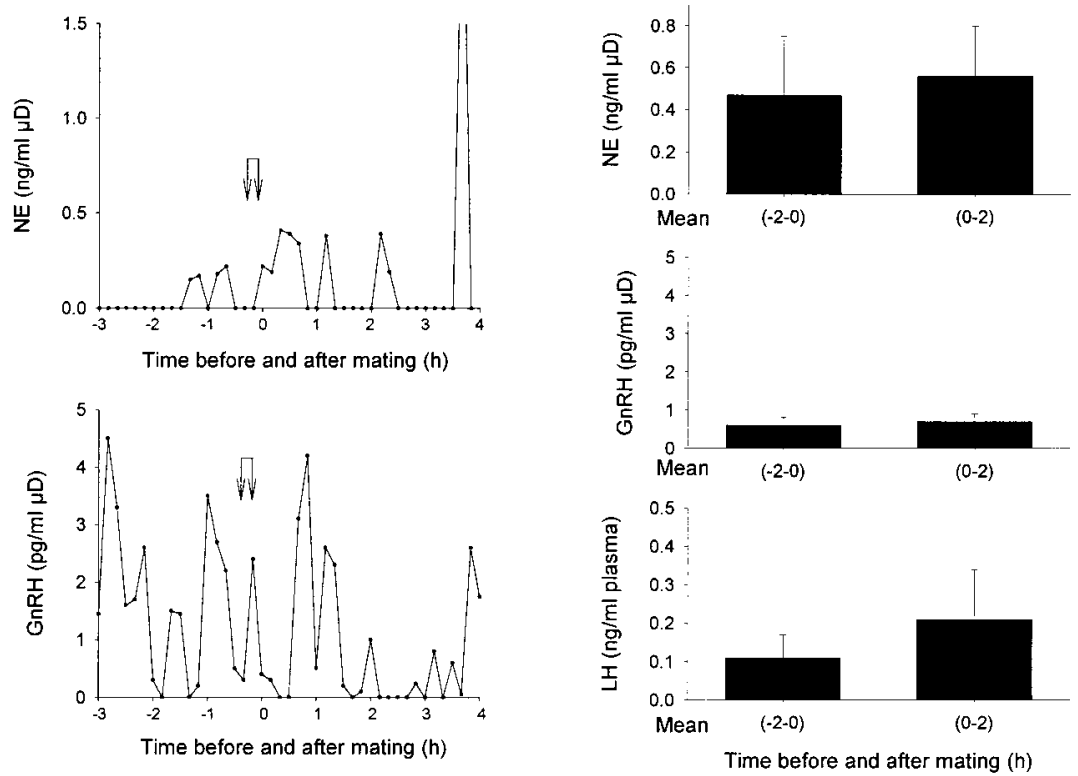

Adapted from Yang et al. (Endocrinology 1996; 137: 2683-2693) 
ministered into the arcuate region median eminence el evated $\mathrm{GnRH}$ rel ease by increasing local NE concentrations (167).

Noradrenergic cells in the rabbit midbrain have been analyzed (168). Cells containing NE, NET, and/or tyrosine hydroxylase (TH), the rate-limiting enzyme in NE synthesis, were localized in the rabbit brain stem using combined immunocytochemistry for dopamine- $\beta$-hydroxylase (DBH), the enzyme specific for NE synthesis, and in situ hybridization for NET and TH (168). NE-, NET-, and $\mathrm{TH}$-containing cells were localized in the A1 and $\mathrm{A} 2$ cell groups and the area postrema of the medulla of the female rabbit. The pons, the locus coereuleus (LC or A6 cell group), and the A5 cell group all expressed NE, NET, and $\mathrm{TH}$. The distribution of NE cells in the rabbit is similar to that of the rat (e.g., 100). Y ang et al. (248) showed that the receipt of mating stimulation increased TH and NET mRNA levels in the LC of female rabbits. Likewise, in estrous ferrets (229), the receipt of an intromission significantly augmented the percentage of TH-IR neurons colabeled with nuclear Fos protein in both the LC (A6) and the rostral A2 cell groups. Taken together, these data demonstrate a pivotal role for NE in the preovulatory release of $\mathrm{GnRH}$ in rabbits and ferrets. The available evidence points to the LC as one of the brain sites important for conveying genital-somatosensory inputs to $\mathrm{GnRH}$ neurons. Lesions of the LC decreased NE input into the medial POA and MBH and consequently blocked the preovulatory LH surge in intact cycling female rats (4). Conversely, electrical stimulation of the LC significantly augmented LH secretion in the rat that was otherwise induced by electrochemical stimulation of the medial POA. Only the brainstem noradrenergic neurons of the A1 and A2 cell groups project to the immediate vicinity of the GnRH cell bodies located in the rat's rostral preoptic area (244), suggesting that LC neurons constitute one segment of a circuit mediating the stimulatory effect of ovarian steroids on $\mathrm{MBH} G \mathrm{GRH}$ output. No information is available about the projections of LC NE neurons in either rabbits or ferrets. Perhaps in induced ovulators genital-somatosensory inputs generated by receipt of an intromission interact with steroidal signals to activate the same NE pathways that in spontaneous ovulators are activated by ovarian steroids alone. An increased release of $\mathrm{GnRH}$ from the $\mathrm{MBH}$ neurons results in both cases.

The activation of the noradrenergic system by mating stimuli is sexually dimorphic in rabbits (247) and ferrets (229). Male rabbits did not display surges in MBH levels of NE or GnRH after coitus (Fig. 9; 247). Correspondingly, TH and NET mRNA levels were not enhanced in the LC of male rabbits

FIG. 9. Sexual dimorphism in the hypothalamic secretion of $\mathrm{GnRH}$ and norepinephrine (NE) after mating in rabbits. Levels are shown of NE and GnRH in 10-min microdialysate and of LH in plasma samples from mated males and females. The line plots show individual profiles of hypothalamic NE and GnRH in representative males and females. Arrows indicate the interval when mating occurred. The bar plots show mean ( \pm SEM) levels of NE, GnRH, and LH before (-2-0) and after (0-2) mating. Note that due to high levels of GnRH in mated females, different scales were used to plot the patterns of $\mathrm{GnRH}$ in mated males and females. 
after mating (248). Likewise in male ferrets (229), mating with intromission did not significantly increase the percentage of TH-IR neurons colabeled with Fos-IR in any brain stem region. These results point to a sexually dimorphic processing of coital signals in the brain stem that results in the activation of brainstem noradrenergic neurons only in females.

\section{Neuropeptide $Y$}

The effects of neuropeptide $Y$ (NPY) on MBH GnRH secretion are well documented in the rabbit. NPY is released from the hypothalamus in a pulsatile manner (117). Intrahypothalamic infusion of NPY stimulates GnRH release in ovariectomized, estradiol-treated female rabbits whereas it inhibits GnRH pulsatile release in ovariectomized does $(117,166)$. These effects of NPY are similar to those of NE $(170,178)$. The mechanism by which NPY stimulates GnRH secretion is currently unknown. However, there is evidence that NPY stimulates $\mathrm{GnRH}$ release via an $\alpha$-adrenergic pathway. When ovariectomized, estrogen-treated female rabbits were infused with prazosin, an $\alpha-1$ receptor antagonist, NPY did not stimulate GnRH release (16). However, administration of yohimbine, an $\alpha-2$ receptor antagonist, did not block the stimulatory action of NPY on GnRH release. These data suggest that NE is an intermediary between NPY and GnRH neurons. NPY mRNA-containing neurons have been localized in the lateral tegmentum (A1) and the nucleus of the solitary tract (A2), the same regions that were immunoreactive for $\mathrm{DBH}$, in the rabbit (168). In the rat $(52,193)$, the A2 cell group projects to the paraventricular and supraoptic nuclei of the hypothalamus. However, this pathway probably does not contain NPY as the putative transmitter in the rat (194). It is possible, however, that in the rabbit this pathway involves NPY.

\section{Opioid Peptides}

The role of endogenous opioid peptides in the regulation of GnRH secretion has been studied extensively (reviewed in 72, 109, 249). There is considerable evidence that endogenous opioid peptides tonically inhibit POA GnRH neurons in rats. Chronic treatment with morphine blocked GnRH secretion (42) and decreased POA GnRH mRNA levels (133), whereas the opioid receptor antagonist naloxone increased plasma LH levels and POA GnRH mRNA levels. Several studies suggest that endogenous opioids inhibit LH secretion in rabbits $(163,250)$, ferrets (120), and cats (101). Female rabbits showed a dramatic rise in LH pulse amplitudes and mean LH levels when given an intravenous infusion of naloxone 2 weeks after gonadectomy. However, no LH response to naloxone was obtained in female rabbits that were gonadally intact and in estrus (163). In another study (250), naloxone effectively raised LH pulse amplitudes in female rabbits tested after ovariectomy. Treatment with estradiol blocked this LH response to naloxone. Likewise, administration of nalox- 
one increased LH pulse frequency in both gonadectomized male and female ferrets (120). As in rabbits, these stimulatory effects of naloxone on LH secretion disappeared when estradiol was given to the gonadectomized ferrets. In cats (101), intravenous injections of naloxone induced LH release in ovariectomized females that were anesthetized; however, the effects of estradiol replacement on this LH response to naloxone were not studied.

In spontaneous ovulators it has been suggested that the neural mechanisms underlying the steroid-induced preovulatory surge of $\mathrm{GnRH}$ and $\mathrm{LH}$ secretion may include both excitation and the removal of inhibitory inputs (108). This disinhibition may reflect, in part, a reduction in opioid inhibitory tone. By contrast, in induced ovulators the neural signals that induce a preovulatory LH surge may be primarily excitatory. As such, there is no important role for endogenous opioid peptides in the regulation of $\mathrm{MBH}$ GnRH release in these animals. In rats, arcuate nucleus concentrations of $\beta$-endorphin (e.g., 192) and proopiomelanocortin (POMC; 24 ) mRNA levels, the precursor of $\beta$-endorphin, have been found to fluctuate over the estrous cycle. POMC mRNA levels declined before the onset of the preovulatory LH surge and then rose again dramatically during the surge (24). Estrogen treatment of ovariectomized female rats decreased arcuate levels of POMC mRNA, with the greatest decrease occurring in the late afternoon just prior to the preovulatory LH surge. By contrast, treatment of ovariectomized female rats with progesterone initially decreased and then stimulated arcuate levels of POMC mRNA (171). Taken together, these results suggest that the occurrence of a preovulatory $\mathrm{LH}$ surge in spontaneous ovulators may result from an estrogen- and progesterone-induced removal of the inhibitory influence of $\beta$-endorphin. The progesterone-induced increase in $\beta$-endorphinergic activity may be a mechanism for terminating the $\mathrm{LH}$ surge. By contrast, there is no clear evidence that opioids play a role in the mating-induced preovulatory LH surge. Treatment with naloxone stimulated $\mathrm{LH}$ release only in the absence of circulating estradiol. Obviously, considerable estrogenic stimulation is normally present during periods of estrus in induced ovulators.

\section{Other Neurotransmitters and Neuropeptides}

The possible contributions of several other neurotransmitters to the regulation of GnRH and LH secretion have been examined in rabbits. Intravenous administration of atropine, which selectively blocks cholinergic muscarinic receptors, blocked ovulation in female rabbits, provided the drug was administered immediately after coitus (196). This finding raises the possibility that the neural circuit controlling mating-induced release of $\mathrm{GnRH}$ includes a cholinergic component that impinges on an adrenergic component.

The role of substance $P$ in $\mathrm{GnRH}$ secretion has been studied in the rabbit (214). In the rat (215) substance-P-containing perikarya located in the arcuate nucleus project to the internal and external layers of the median eminence. In addition substance-P-containing neurons have been found to synapse with 
GnRH-IR soma and dendrites in the rostral POA. Despite these anatomical links (215), the effects of substance P on LH secretion have been equivocal in rats (reviewed in 108). In rabbits (214), injection of substance $P$ into the third ventricle augmented $\mathrm{LH}$ secretion in both intact and ovariectomized females. However, administration of substance $P$ was effective only when applied during the rising, but not declining, phase of a $\mathrm{LH}$ peak, suggesting only a modulatory role of substance $\mathrm{P}$ in $\mathrm{GnRH}$ release. Thus, whether hypothalamic substance $\mathrm{P}$ participates in the postcoital preovulatory discharge of $\mathrm{GnRH}$ from the $\mathrm{MBH}$ remains unknown.

\section{ROLE OF PITUITARY GRRH RECEPTORS IN THE PREOVULATORY LH SURGE}

The amount of $\mathrm{LH}$ secreted in response to the $\mathrm{MBH}$ release of $\mathrm{GnRH}$ depends on the number of $\mathrm{GnRH}$ receptors $(\mathrm{R})$ present on the plasma membrane of the pituitary gonadotropes (239). In spontaneous ovulators, including rats (3), sheep (50), and humans (221), a single intravenous injection of $\mathrm{GnRH}$ increases pituitary sensitivity to subsequent pulses of $\mathrm{GnRH}$, presumably by increasing GnRH-R numbers (e.g., 216). As a result, consecutive short pulses of $\mathrm{GnRH}$ will ultimately lead to a much larger release of $\mathrm{LH}$ from the pituitary. By contrast, continuous infusion of $\mathrm{GnRH}$ leads to a decrease in $\mathrm{GnRH}-\mathrm{R}$ numbers, thereby desensitizing the pituitary to the LH-releasing capacity of $\mathrm{GnRH}(51,162)$. Thus, $\mathrm{GnRH}$ is a key regulator of pituitary $\mathrm{GnRH}-\mathrm{R}$ levels and thereby the magnitude of any $\mathrm{LH}$ surge in spontaneous ovulators. To date, attempts $(61,151)$ using induced ovulators to demonstrate $\mathrm{GnRH}$-induced changes in pituitary sensitivity to subsequent GnRH exposure have been unsuccessful. Donovan and ter Haar (61) found that three consecutive intravenous injections of GnRH given at hourly intervals induced repetitive $\mathrm{LH}$ surges in female ferrets. However, there was no sign of any modulating effect of the second or third GnRH injection on the magnitude of the resultant LH surges. Likewise, two injections of GnRH (separated by 20 or $60 \mathrm{~min}$ ) did not increase pituitary sensitivity in the vole (M. agrestis; 151). However, a self-priming effect of $\mathrm{GnRH}$ on later pituitary sensitivity to additional $\mathrm{GnRH}$ stimulation may occur in the cat. As already explained, several studies suggest that repeated mating triggers episodes of $\mathrm{GnRH}$ release, thereby producing cumulative increments in LH secretion needed to stimulate ovulation in this species $(47,107,238)$. Thus far, priming effects of GnRH on the pituitary have been studied only in the male cat. Goodrowe et al. (81) showed that a second injection of GnRH produced a second LH surge. However, this second response was smaller and shorter in duration than the first one, suggesting a desensitization of the pituitary by $\mathrm{GnRH}$. Thus, in contrast to spontaneous ovulators in which preovulatory LH surges may partly depend upon the self-priming effect of $\mathrm{GnRH}$ in gonadotropes (e.g., 223), there is very little evidence for any self-priming effect of $\mathrm{GnRH}$ on $\mathrm{LH}$ secretion in induced ovulating species. 


\section{CONCLUDING REMARKS}

The role of GnRH in stimulating pituitary LH secretion is well established for both spontaneously and induced ovulating species. By contrast, our understanding of the neuroendocrine mechanisms controlling GnRH synthesis and release in either spontaneous or induced ovulators is still very limited. It is not clear how sensory stimuli associated with mating reach and activate for ebrain $\mathrm{GnRH}$ neurons in induced ovulators. In addition, how estrogen exerts its inhibitory and/or stimulatory actions on GnRH neurons has been difficult to establish in both spontaneous and induced ovulators. Finally, how GnRH neurons distributed diffusely throughout the medial basal forebrain coordinate the release of discrete pulses of $\mathrm{GnRH}$ into the median eminence remains largely unknown. It is possible that GnRH neurons actually form an interconnected network. Synapses have been shown between GnRH neurons (40, 41, $128,146,213,240)$. In addition, in vitro studies (119) of GT1-7 cells, the immortalized mouse GnRH neuronal cell line, showed that these cells expressed the message and the protein for the GnRH-receptor. Another possibility is that $\mathrm{GnRH}$ release from nerve terminals is coordinated at the median eminence by other neurotransmitter or peptidergic systems such as NE and NPY (activational) or by opioids (inhibitory). Because GnRH plays such a pivotal role in reproduction, it is likely that multiple neuroendocrine mechanisms have evolved to control its release. Thus, the interruption of one particular pathway such as the one that controls estradiol-induced GnRH output, does not necessarily eliminate the possibility of $\mathrm{GnRH}$ release leading to a preovulatory LH surge, as demonstrated by the occurrence of mating-induced ovulation in the persistently estrous rat. The fact that the neuroendocrine mechanisms controlling both induced and spontaneous ovulation are intertwined in many mammalian species warrants further study. To what extent do the neural inputs to forebrain GnRH neurons differ between induced and spontaneous ovulators? There is strong evidence in both spontaneous and induced ovulators pointing to an activation of brainstem and midbrain noradrenergic neurons prior to the preovulatory release of GnRH (reviewed in 208). By contrast, there is no clear evidence that endogenous opioid peptides are part of the neural circuit conveying genital-somatosensory inputs to forebrain GnRH neurons in induced ovulators, probably because the neural signal for inducing a preovulatory LH surge is primarily excitatory in these species. Future studies using both induced and spontaneously ovulating species will help elucidate the neural circuitry controlling MBH GnRH release.

\section{ACKNOWLE DGMENTS}

Preparation of this review was supported by funds from NIH Grant HD21094 and from NIMH Research Scientist Award MH 00392. We thank Dr. Sarah Woodley for critical reading of an earlier version of this paper. 


\section{REFERENCES}

1. Adams CE. Observations on the induction of ovulation and expulsion of uterine eggs in the mink, Mustela vision. J Reprod Fertil 1981; 63: 241-248.

2. Adelman J P, Mason AJ , Hayflick J S, Seeburg PH. I solation of the gene and hypothalamic CDNA for the common precursor of gonadotropin-releasing hormone and prolactin releaseinhibiting factor in human and rat. Proc Natl Acad Sci USA 1986; 83: 179-183.

3. Aiyer MS, Chiappa SA, Fink G. A priming effect of luteinising hormone releasing factor on the anterior pituitary gland in the female rat. J Endocrinol 1974; 62: 573-588.

4. Anselmo-Franci J A, Franci CR, Krulich L, Antunes-Rodrigues J , McCann SM. Locus coeruleus lesions decrease norepinephrine input into the medial preoptic area and medial basal hypothalamus and block the LH, FSH, and prolactin preovulatory surge. Brain Res 1997; 767: 289-296.

5. Antunes-Rodrigues J, McCann SM. Effect of suprachiasmatic lesions on the regulation of luteinizing hormone secretion in the female rat. Endocrinology 1967; 81: 666-670.

6. Asdell SA. Patterns of Mammalian Reproduction, 2nd ed. Ithaca, New York: Comstock, 1964.

7. Bakker J , Baum MJ . Gonadal steroids modulate pituitary LH secretion, but not mediobasal hypothalamic GnRH mRNA levels in the ferret. J Reprod Fertil (in press) J uly 2000.

8. Bakker J, Rubin BS, Baum MJ . Changes in mediobasal hypothalamic gonadotropin-releasing hormone messenger ribonucleic acid levels induced by mating or ovariectomy in a reflex ovulator, the ferret. Endocrinology 1999; 140: 595- 602.

9. Barraclough CA, Wise PM. The role of catecholamines in the regulation of pituitary luteinizing hormone and follicle-stimulating hormone secretion. Endocr Rev 1982; 3: 91-119.

10. Barry J. Characterization and topography of LHRH neurons in the rabbit. Neurosci Lett 1976; 2: 201-205.

11. Baum MJ, Bressler SC, Daum MC, Vega CA, McNamee CS. Ferret mothers provide more anogenital licking to male offspring: Possible contribution to psychosexual differentiation. Physiol Behav 1996; 60: 353-359.

12. Baum MJ, Carroll RS, Cherry J A, Tobet SA. Steroidal control of behavioural, neuroendocrine and brain sexual differentiation: Studies in a carnivore, the ferret. J Neuroendocrinol 1990; 2: 401- 418.

13. Baum MJ , Gerlach J L, Krey LC, McE wen BS. Biochemical and radioautographic analysis of estrogen-inducible progestin receptors in female ferret brain and pituitary: Correlations with effects of progesterone on sexual behavior and gonadotropin-releasing hormone-stimulated secretion of luteinizing hormone. Brain Res 1986; 368: 296-309.

14. Baum MJ , Keverne EB, Everitt BJ , Herbert J, de Greef WJ . Effects of progesterone and estradiol on sexual attractivity of female rhesus monkeys. Physiol Behav 1977; 18: 659- 670.

15. Baum MJ, Schretlen PJ. Oestrogenic induction of sexual behaviour in ovariectomized ferrets housed under short or long photoperiods. J Endocrinol 1978; 78: 295-296.

16. Berria M, Pau K-YF, Spies HG. Evidence for al pha 1-adrenergic involvement in neuropeptide Y-stimulated GnRH release in female rabbits. Neuroendocrinology 1991; 53: 480- 486.

17. Berriman SJ, Wade GN, Blaustein J D. Expression of Fos-like proteins in gonadotropinreleasing hormone neurons of Syrian hamsters: Effects of estrous cycles and metabolic fuels. Endocrinology 1992; 131: 2222-2228.

18. Beyer C, McDonald P. Hormonal control of sexual behaviour in the female rabbit. Adv Reprod Physiol 1973; 6: 185-219.

19. Bibeau CE, Tobet SA, Anthony ELP, Carroll RS, Baum MJ, King J C. Vaginocervical stimulation of ferrets induces release of luteinizing hormone-releasing hormone. J Neuroendocrinol 1991; 3: 29-36. 
20. Billings $\mathrm{HJ}$, Katz LS. Progesterone facilitation and inhibition of estradiol-induced sexual behavior in the female goat. Horm Behav 1997; 31: 47-53.

21. Birkhead TR. Sperm competition: Evolution and mechanisms. Curr Top Dev Biol 1996; 33: 103-158.

22. Bissonette TH. Modification of mammalian sexual cycles: Reactions of ferrets of both sexes to electric light added after dark in November and December. Proc R Soc London Biol 1932; 110: 322.

23. Blaustein J D, Fleder HH. Cytoplasmic progesterone receptors in guinea pig brain: Characterization and relationship to the induction of sexual behavior. Brain Res 1979; 169: 481- 497.

24. Bohler HC, Tracer H, Merriam GR, Petersen SL. Changes in proopiomelanocortin messenger ribonucleic acid levels in the rostral periarcuate region of the female rat during the estrous cycle. Endocrinol. 1991; 128: 1265-1269.

25. Brann DW, Mahesh VB. Excitatory amino acids: Function and significance in reproduction and neuroendocrine regulation. Front Neuroendocrinol 1994; 15: 3- 49.

26. Bronson FH. Rodent pheromones. Biol Reprod 1971; 4: 344-357.

27. Brown-Grant K, Raisman G. Abnormalities in reproductive function associated with the destruction of the suprachiasmatic nuclei in female rats. Proc R Soc London B Biol Sci 1977; 198: 279-296.

28. Caba M, Beyer C, González-Mariscal G, Silver R. Sexual difference in the effect of mating on gonadotropin releasing hormone $(\mathrm{GnRH})$ neurons expressing Fos protein in the rabbit forebrain. Society for Neuroscience meeting 1998; Abst 144.3.

29. Caraty A, Locatelli A. Effect of time after castration on secretion of GnRH and LH in the ram. J Reprod Fert 1988; 82: 263-269.

30. Carmel PW, Araki S, Ferin M. Pituitary stalk portal blood collection in rhesus monkeys: Evidence for pulsatile release of gonadotropin-releasing hormone $(\mathrm{GnRH})$. Endocrinol ogy 1976; 99: 243-248.

31. Carroll RS, Baum MJ. Evidence that oestrogen exerts an equivalent negative feedback action on LH secretion in male and female ferrets. J Reprod Fertil 1989; 86: 235-245.

32. Carroll RS, Erskine MS, Baum MJ. Sex difference in the effect of mating on the pulsatile secretion of luteinizing hormone in a reflex ovulator, the ferret. Endocrinology 1987; 121: 1349-1359.

33. Carroll RS, Erskine MS, Doherty PC, Lundell LA, Baum MJ . Coital stimuli controlling luteinizing hormone secretion and ovulation in the female ferret. Biol Reprod 1985; 32: 925-933.

34. Carter CS, Getz LL. Social and hormonal determinants of reproductive patterns in the prairie vole. In Gilles R, Balthazart J (Eds). Neurobiology. Berlin: Springer-Verlag, 1985: 18-36.

35. Carter CS, Getz LL, Gavish L, McDermott J L, Arnold P. Male-related pheromones and the activation of female reproduction in the prairie vole (Microtus ochrogaster). Biol Reprod 1980; 23: 1038-1045.

36. Carter CS, Witt DM, Manock SR, Adams KA, Bahr J M, Carlstead K. Hormonal correlates of sexual behavior and ovulation in male-induced and postpartum estrus in female prairie voles. Physiol Behav 1989; 46: 941-948.

37. Cattanach HM, Iddon CA, Charlton HM, Chiappa S, Fink G. Gonadotropin-releasing hormone deficiency in a mutant mouse with hypogonadism. Nature 1977; 269: 338-340.

38. Charlton HM, Naftolin F, Sood MC, Worth RW. The effect of mating upon LH release in male and female voles of the species Microtus agrestis. J Reprod Fertil 1975; 42: 167-170.

39. Chemineau P. Possibilities for using bucks to stimulate ovarian and oestrus cycles in anovulatory goats. Livest Prod Sci 1987; 17: 135-147. 
40. Chen W-P, Witkin J W, Silverman AJ . Beta-endorphin and gonadotropin-releasing hormone synaptic input to gonadotropin-releasing hormone neurosecretory cells in the male rat. J Comp Neurol 1989; 286: 85-95.

41. Chen WP, Witkin J W, Silverman AJ. Sexual dimorphism in the synaptic input to gonadotropin releasing hormone neurons. Endocrinology 1990; 126: 695-702.

42. Ching M. Morphine suppresses the proestrous surge of GnRH in pituitary portal plasma of rats. Endocrinology 1983; 112: 2209-2211.

43. Clark IJ , Thomas GB, Yao B, Cummins J T. GnRH secretion throughout the ovine estrous cycle. Neuroendocrinology 1987; 46: 82- 88.

44. Cohen-Parsons M, Carter CS. Males increase serum estrogen and estrogen receptor binding in brain of female voles. Physiol Behav 1987; 39: 309-314.

45. Cohen-Parsons $\mathrm{M}$, Carter CS. Males increase progestin receptor binding in brain of female voles. Physiol Behav 1988; 42: 191-197.

46. Conaway $\mathrm{CH}$. Ecological adaptation and mammalian reproduction. Biol Reprod 1971; 4: 239-241.

47. Concannon P, Hodgson B, Lein D. Reflex LH release in estrous cats following single and multiple copulations. Biol Reprod 1980; 23: 111-117.

48. Crews D, Grassman M, Lindzey J. Behavioral facilitation of reproduction in sexual and unisexual whiptail lizards. Proc Natl Acad Sci USA 1986; 83: 9547-9550.

49. Crews DP, Silver R. Reproductive physiology and behavior interactions in nonmammalian vertebrates. In: Adler N, Pfaff D, Goy RW, Eds. Handbook of Behavioral Neurobiology, Vol 7. New York: Plenum, 1985: 101-182.

50. Crighton DB, Foster JP. Luteinising hormone release after two injections of synthetic luteinising hormone-releasing hormone in the ewe. J Endocrinol 1977; 72: 59-67.

51. Crowder ME, Herring RD, Nett TM. Rapid recovery from gonadotrope function after downregulation of receptors for GnRH in ewes. J Reprod Fertil 1986; 78: 577-585.

52. Cunningham ETJ, Sawchenko PE. Anatomical specificity of noradrenergic inputs to the paraventricular and supraoptic nuclei of the rat hypothalamus. J Comp Neurol 1988; 274: 60-76.

53. DeBold J F, Martin J V, Whalen RE. The excitation and inhibition of sexual receptivity in female hamsters by progesterone: Time and dose relationships, neural colocalization and mechanisms of action. Endocrinology 1976; 99: 1519-1527.

54. Dellovade TL, King J A, Millar RP, Rissman EF. Presence and differential distribution of distinct forms of immunoreactive gonadotropin-rel easing hormone in the musk shrew brain. Neuroendocrinol ogy 1993; 58: 166-177.

55. Dellovade TL, Ottinger MA, Rissman EF. Mating alters gonadotropin-releasing hormone cell number and content. Endocrinology 1995; 136: 1648-1657.

56. Dempsey EW, Searles HF. Environmental modification of certain endocrine phenomena. Endocrinology 1943; 32: 119-128.

57. Dewsbury DA. Copulatory behavior of montane voles (Microtus montanus). Behaviour 1973; 44: 186-202.

58. Dhillon H, Dunn AM, Esquival E, Hamernik DL, Wise ME. The estradiol-induced luteinizing hormone surge in the ewe is not associated with increased gonadotropin-releasing hormone messenger ribonucleic acid levels. Biol Reprod 1997; 57: 107-111.

59. Dluzen DE, Carter CS. Ovarian hormones regulating sexual and social behaviors in female prairie voles, Microtus Ochrogaster. Physiol Behav 1979; 23: 597- 600.

60. Doan A, Urbanski HF. Diurnal expression of F os in luteinizing hormone releasing hormone neurons of Syrian hamsters. Biol Reprod 1994; 50: 301-308.

61. Donovan BT, ter Haar MB. Effects of LH-releasing hormone on plasma FSH and LH levels in the ferret. J Endocrinol 1977; 73: 37-52. 
62. Donovan BT, Matson C, Kilpatrick MJ. Effect of exposure to long days on the secretion of oestradiol, oestrone, progesterone, testosterone, androstenedione, cortisol and follicle-stimulating hormone in intact and spayed ferrets. J . Endocrinol 1983; 99: 361-368.

63. Dryden GL. Reproduction in Suncus murinus. J Reprod Fert Suppl 1969; 6: 377-396.

64. Dufy-Barbe L, Franchimont P, Faure J M. Time courses of LH and FSH rel ease after mating in the female rabbit. Endocrinology 1973; 92: 1318-1321.

65. Edwards RG. Test-tube babies, 1981. Nature 1981; 293: 253-256.

66. Emanuele NV, J urgens J , La Paglia N, Williams DW, Kelley MR. The effect of castration on steady state levels of luteinizing hormone-releasing hormone $(\mathrm{LHRH}) \mathrm{mRNA}$ and proL HRH processing: Time course study utilizing semi-quantitative reverse transcription/polymerase chain reaction. J Endocrinol 1996; 148: 509-515.

67. Enders RK. Reproduction in the mink (Mustela vision). Proc Am Philos Soc 1952; 96: 691-755.

68. Eskay RL, Mical RS, Porter J C. Relationship between luteinizing hormone releasing hormone concentration in hypophysical blood and luteinizing hormone release in intact, castrated, and electrochemically-stimulated rats. Endocrinology 1977; 100: 263-270.

69. Everett J W. Spontaneous persistent estrus in a strain of al bino rats. Endocrinology 1939; 25: 123-127.

70. Everett J W. The mammalian reproductive cycle and its controlling mechanisms. In: Young WC, Ed. Sex and Internal Secretions, 3rd ed. Baltimore: Williams \& Wilkins, 1961; Vol II, 497-555.

71. Fadem $\mathrm{BH}$. The effects of pheromonal stimuli on estrus and peripheral plasma estradiol in female gray short-tailed opossums (Monodel phis domestica). Biol Reprod 1989; 41: 231-217.

72. Ferin M, Van Vugt D, Wardlaw S. The hypothalamic control of the menstrual cycle and the role of endogenous opioid peptides. Recent Prog Horm Res 1984; 40: 441- 485.

73. Fernandez-Baca S, Madden DHL, Novoa C. Effect of different mating stimuli on induction and ovulation in the alpaca. J Reprod Fertil 1970; 22: 261-267.

74. Finn PD, Steiner RA, Clifton DK. Temporal patterns of gonadotropin-releasing hormone $(\mathrm{GnRH}), \mathrm{c}-\mathrm{fos}$, and galanin gene expression in $\mathrm{GnRH}$ neurons relative to the luteinizing hormone surge in the rat. J Neurosci 1996; 18: 713-719.

75. Fortune J E, Eppig J , Rissman EF. Mating stimulates estradiol production by ovaries of the musk shrew (Suncus murinus). Biol Reprod 1992; 46: 885- 891.

76. Gautron J P, Leblanc P, Bluet-Pajot MT, Pattou E, L'Héritier A, Mounier F, Ponce G, Audinot $\mathrm{V}$, Rasolonjanahary $\mathrm{R}$, Kordon $\mathrm{C}$. A second endogenous molecular form of mammalian hypothalamic luteinizing hormone-releasing hormone (LHRH), (hydroxyproline ${ }^{9}$ ) $\mathrm{LHRH}$, releases luteinizing hormone and follicle-stimulating hormone in vitro and in vivo. Moll Cell Endocrinol 1992; 85: 99-107.

77. Gibson MJ, Wu TJ, Miller GM, Silverman AJ. What nature's knockout teaches us about GnRH activity: Hypogonadal mice and neuronal grafts. Horm Behav 1997; 31: 212-220.

78. Goldsmith PC and Ganong WF. Ultrastructural localization of luteinizing hormone-releasing hormone in the median eminence of the rat. Brain Res 1975; 97: 181-193.

79. Gomendio M, Harcourt AH, Roldan ERS. Sperm competition in mammals. In: Birkhead TR, Møller AP, Eds. Sperm Competition and Sexual Selection. London: Academic Press, 1998: 667-756.

80. Goodman AL, Neill J D. Ovarian regulation of postcoital gonadotropin release in the rabbit: Reexamination of a functional role for $20 \alpha$ dihydroprogesterone. Endocrinology 1976; 99: 852- 860.

81. Goodrowe KL, Chakraborty PK, Wildt DE. Pituitary and gonadal response to exogenous LH-releasing hormone in the male domestic cat. J . Endocrinol. 1985; 105: 175-181.

82. Gore AC, Roberts J L. Regulation of gonadotropin-rel easing hormone gene expression in the rat during the luteinizing hormone surge. Endocrinology 1995; 136: 889- 896. 
83. Gore AC, Roberts J L. Regulation of gonadotropin-releasing hormone gene expression in vivo and in vitro. Front Neuroendocrinol 1997; 18: 209-245.

84. Gray GD, Davis HN, Kenney AmcM, Dewsbury DA. The effect of mating on plasma levels of LH and progesterone in montane voles (Microtus montanus). J Reprod Fertil 1976; 47: 89-91.

85. Gudermuth DF, Newton L, Daels P, Concannon P. Incidence of spontaneous ovulation in young, group-housed cats based on serum and faecal concentrations of progesterone. J Reprod Fertil Suppl 1997; 51: 177-184.

86. Guillemin R. Purification, isolation, and primary structure of the hypothalamic luteinizing hormone-releasing factor of ovine origin. A historical account. Am J Obstet Gynecol 1977; 129: $214-218$.

87. Hamada T, Nakajima M, Takeuchi Y, Mori Y. Pheromone-induced stimulation of hypothalamic gonadotropin-releasing hormone pulse generator in ovariectomized, estrogen-primed goats. Neuroendocrinology 1996; 64: 313-319.

88. Hammond J , Marshall FHA. Oestrus and pseudopregnancy in the ferret. Proc R Soc 1930; B105: 607- 630.

89. Harris GW, J acobsohn D. Functional grafts of the anterior pituitary gland. Proc Soc London Biol 1952; 139: 263-270.

90. Harris GW, Naftolin F. The hypothalamus and control of ovulation. Br Med Bull 1970; 26: 3-9.

91. Harris TG, Robinson J E, Evans NP, Skinner DC, Herbison AE. Gonadotropin-releasing hormone messenger ribonucleic acid expression changes before the onset of the estradiolinduced luteinizing hormone surge in the ewe. Endocrinology 1998; 139: 57- 64.

92. Hasler J F, Banks EM. The behavioural and somatic effects of ovariectomy and replacement therapy in female collared lemmings (Dicrostonyx groenlandicus). Biol Reprod 1976; 12: 647- 656.

93. Herbison AE. Noradrenergic regulation of cyclic GnRH secretion. Rev Reprod 1997; 2: 1- 6 .

94. Herbison AE. Multimodal influence of estrogen upon gonadotropin-releasing hormone neurons. Endocr Rev 1998; 19: 302-330.

95. Herbison AE, Robinson J E, Skinner DC. Distribution of estrogen receptor-immunoreactive cells in the preoptic area of the ewe: Co-localization with glutamic acid decarboxylase but not luteinizing hormone-releasing hormone. Neuroendocrinology 1993; 57: 751-759.

96. Hilliard J, Eaton LWM. Estradiol-17 $\beta$, progesterone and $20 \alpha$-hydroxypregn-4-en-3-one in rabbit venous plasma. II. From mating through implantation. Endocrinology 1971; 89: 522-527.

97. Hilliard J, Penardi R, Sawyer $\mathrm{CH}$. A functional role for 20-alpha-hydroxypregn-4-en-3-one in the rabbit. Endocrinology 1967; 80: 901-909.

98. Hind RA. Interaction of internal and external factors in integration of canary reproduction. In: Beach FA, Ed. Sex and Behavior. New York: Wiley, 1965; 381- 415.

99. Hoffman GE, Smith MS, Verbalis J G. C-fos and related immediate early gene products as markers of activity in neuroendocrine systems. Front Neuroendocrinol 1993; 14: 173-213.

100. Hokfelt T, Martenson R, Bjorklund A, Kleinau S, Goldstein M. Distributional maps of tyrosine-hydroxylase-immunoreactive neurons in the rat brain. In: Bjorklund A, Hokfelt T, Eds. Handbook of Chemical Neuroanatomy, Vol 2. Classical Neurotransmitters in the CNS, Part I. Amsterdam: Elsevier Science, 1984: 277-379.

101. Hubbart J I, Hyland BI, Sirett NE. Stimulation of the LH release by naloxone in anaesthetized cats after ovariectomy. Neurosci Lett 1990; 108: 295-302.

102. Huck UW, Carter CS, Banks EM. Estrogen and progesterone interactions influencing sexual and social behaviour in the brown lemming (Lemmus trimucronatus). Horm Behav 1979; 12: 40- 49.

103. J öchle W. Coitus induced ovulation. Contraception 1973; 7: 523-564. 
104. J öchle W. Current research in coitus-induced ovulation: A review. J Reprod Fertil Suppl 1975; 22: 165-207.

105. J ones EF, Bain J B, Odell WD. Postcoital luteinizing hormone release in male and female rabbits as determined by radioimmunoassay. Fertil Steril 1976; 27: 848-852.

106. J ohnson LM, Gay VL. Luteinizing hormone in the cat. I. Tonic secretion. Endocrinology 1981; 109: 240-246.

107. J ohnson LM, Gay VL. Luteinizing hormone in the cat. II. Mating-induced secretion. Endocrinology 1981; 109: 247-252.

108. Kalra SP. Mandatory neuropeptide-steroid signaling for the preovulatory luteinizing hormone-releasing hormone discharge. Endocr Rev 1993; 14: 507-538.

109. Kalra SP, Kalra PS. Neural regulation of luteinizing hormone secretion in the rat. Endocr Rev 1983; 4: 311-351.

110. Kalra SP, Kalra PS. Do testosterone and estradiol-17 $\beta$ enforce inhibition or stimulation of luteinizing hormone-releasing hormone secretion? Biol Reprod 1989; 41: 559-570.

111. Karsch FJ, Cummins J T, Thomas GB, Clarke IJ. Steroid feedback inhibition of pulsatile secretion of gonadotropin-releasing hormone in the ewe. Biol Reprod 1987; 36: 1207-1218.

112. Karsch FJ , Weick RF, Butler WR, Dierschke DJ , Krey LC, Weiss G, Hotchkiss J , Yamaji T, Knobil E. Induced LH surges in the rhesus monkey: Strength-duration characteristics of the estrogen stimulus. Endocrinology 1973; 92: 1740-1747.

113. Kasten TL, White SA, Norton TT, Bond CT, Adelman J P, Fernald RD. Characterization of two new preproGnRH mRNAs in the tree shrew: First direct evidence for mesencephalic GnRH gene expression in a placental mammal. Gen Comp Endocrinol 1996; 104: 7-19.

114. Kaynard AH, Pau K-YF, Hess DL, Spies HG. Gonadotropin-releasing hormone and norepinephrine rel ease from the rabbit mediobasal and anterior hypothalamus during the matinginduced luteinizing hormone surge. Endocrinol ogy 1990; 127: 1176-1185.

115. Kelly MJ, Garrett J, Bosch MA, Roselli CE, Douglass J, Adelman J P, Ronnekleiv OK. Effects of ovariectomy on GnRH mRNA, proGnRH and GnRH levels in the preoptic hypothalamus of the female rat. Neuroendocrinology 1989; 49: 88-97.

116. Kenney AmcM, Dewsbury, DA. Effect of limited mating on the corpora lutea in montane voles, Microtus montanus. J Reprod Fertil 1977; 49: 363-364.

117. Khorram O, Pau K-YF, Spies HG. Release of hypothalamic neuropeptide $Y$ and effects of exogenous NPY on the release of hypothalamic GnRH and pituitary gonadotrophs in intact and ovariectomized does in vitro. Peptides 1988; 9: 411- 417.

118. King J A, Steneveld AA, Curlewis J D, Rissman EF, Millar RP. Identification of chicken GnRH II in brains of metatherian and early-evolved eutherian species of mammals. Regul Pep 1994; 54: 467- 477.

119. Krsmanovic LZ, Stojilkovic SS, Mertz LM, Tomic G, Catt KJ . Expression of gonadotropinreleasing hormone receptors and autocrine regulation of neuropeptide release in immortalized hypothalamic neurons. Proc Natl Acad Sci USA 1993; 90: 3908-3912.

120. Lambert GM, Erskine MS, Baum MJ. Effect of naloxone on the pulsatile secretion of luteinizing hormone in gonadectomized male and female ferrets before and after oestradiol replacement. J Neuroendocrinol 1990; 2: 701-705.

121. Lambert GM, Rubin BS, Baum MJ. Sexual dimorphism in the effects of mating on the in vitro release of LHRH from the ferret mediobasal hypothalamus. Physiol Behav 1992a; 52: 809-813.

122. Lambert GM, Rubin BS, Baum MJ . Sex difference in the effect of mating on c-fos expression in luteinizing hormone-releasing hormone neurons of the ferret forebrain. Endocrinology 1992b; 131: 1473-1480.

123. Lawler DF, J ohnston SD, Hegstad RL, Keltner DG, Owens SF. Ovulation without cervical stimulation in domestic cats. J Reprod Fertil Suppl 1993; 47: 57-61. 
124. Leavitt WW, Chen TJ, Allen TC, J ohnston TON. Regulation of progesterone receptor formation by estrogen action. Ann NY Acad Sci 1977; 286: 210-225.

125. Lee WS, Smith S, Hoffman GE. Luteinizing hormone-releasing hormone neurons express fos protein during the proestrous surge of luteinizing hormone. Proc Natl Acad Sci USA 1990; 87: 5163-5167.

126. Lehman MN, Karsch FJ . Do gonadotropin-releasing hormone, tyrosine hydroxylase and $\beta$-endorphin-immunoreactive neurons contain estrogen receptors? A double-label immunocytochemical study in the suffolk ewe. Endocrinology 1993; 133: 887- 895.

127. Lehrman DS. Interaction between internal and external environments in the regulation of the reproductive cycle of the ring dove. In: Beach FA, Ed. Sex and Behavior. New York: Wilkins, 1965: 355-380.

128. Léránth C, Seguraum LMG, Palkovits M, MacLusky J, Shanabrough M, Naftolin F. The $\mathrm{LH}-\mathrm{RH}$-containing neuronal network in the preoptic area of the rat: Demonstration of $\mathrm{LH}-\mathrm{RH}$-containing nerve terminals in synaptic contact with $\mathrm{LH}-\mathrm{RH}$ neurons. Brain Res 1985; 345: 332-336.

129. Lescheid DW, Terasawa E, Abler LA, Urbanski HF, Warby CM, Millar RP, Sherwood NM. A second form of gonadotropin-releasing hormone $(\mathrm{GnRH})$ with characteristics of chicken GnRH-II is present in the primate brain. Endocrinology 1997; 138: 5618-5629.

130. Levine J E, Pau K-YF, Ramirez VD, J ackson GL. Simultaneous measurement of luteinizing hormone-rel easing hormone and luteinizing hormone release in unanesthetized, ovariectomized sheep. Endocrinology 1982; 111: 1449-1455.

131. Levine J E, Ramirez VD. Luteinizing hormone-releasing hormone release during the rat estrous cycle and after ovariectomy, as estimated by push-pull cannulae. Endocrinology 1982; 111: 1439-1448.

132. Levine JE, Ramirez VD. Measurements of neuropeptide release: In vitro and in vivo procedures. Methods Enzymol 1986; 124: 466- 494.

133. Li W, Pelletier G. Opioid regulation of gonadotropin-releasing hormone gene expression in the male rat brain as studied by in situ hybridization. Neuroreport 1993; 4: 331-333.

134. Lin WW, Ramirez VD. Effect of pulsatile infusion of progesterone on the in vivo activity of the luteinizing hormone-releasing hormone neural apparatus of awake unrestrained female and male rabbits. Endocrinology 1988; 122: 868-876.

135. Lin WW, Ramirez VD. Infusions of progestins into the hypothalamus of female New Zealand white rabbits: Effect on in vivo luteinizing hormone-releasing hormone release as determined with push-pull perfusion. Endocrinology 1990; 126: 261-272.

136. Lin WW, Ramirez VD. Effect of mating behavior on luteinizing-hormone releasing hormone release in female rabbits as monitored with push-pull cannulae. Neuroendocrinology 1991; 53: 229-235.

137. MacLusky NJ, Lieberburg I, Krey LC, McEwen BS. Progestin receptors in the brain and pituitary of the bonnet monkey: Differences between the monkey and the rat in the distribution of progestin receptors. Endocrinology 1980; 106: 185-191.

138. MacLusky NJ , McE wen BS. Progestin receptor in the rat brain: Distribution and properties of cytoplasmic binding sites. Endocrinology 1980; 106: 192-202.

139. Malik KF, Silverman AJ, Morrell JI. Gonadotropin-releasing hormone mRNA in the rat: Distribution and neuronal content over the estrous cycle and after castration of males. Anat Rec 1991; 231: 457- 466.

140. Marie M, Anouassi A. Mating-induced luteinizing hormone surge and ovulation in the female camel (Camelus dromedarius). Biol Reprod 1986; 35: 792-798.

141. Marion GD. The effect of sterile copulation on time of ovulation in dairy heifers. J Dairy Sci 1950; 33: 885- 889.

142. Marsden HM, Bronson FH. Estrous synchrony in mice: Alteration by exposure to male urine. Science 1964; 144: 3625. 
143. Marshall FHA. The oestrous cycle of the common ferret. Q J Microsc Sci 1904; 48: 323-345.

144. McCann SM, Taleisnik S, Friedman HM. LH-releasing activity in hypothalamic extracts. Proc Soc Exp Biol 1960; 104: 432- 434.

145. Mendonca MT, Crews D. Effect of fall mating on ovarian development in the red-sided garter snake. Am J Physiol 1989; 257: R1548-1550.

146. Merchenthaler I, Görcs T, Sétáló G, Petrusz P, Flerkó B. Gonadotropin-releasing hormone $(\mathrm{GnRH})$ neurons and pathways in the rat brain. Cell Tissue Res 1984; 237: 15-29.

147. Millar RP, King J A. Plasticity and conversation in gonadotropin-releasing hormone structure. In: Davey KG, Peter RE, Tobe SS, Eds. Perspectives in Comparative Endocrinology. Ottawa: National Research Council of Canada, 1994: 129-136.

148. Milligan SR. Mating, ovulation, and corpus luteum function in the vole, Microtus agrestis. J Reprod Fertil 1975; 42: 35- 44.

149. Milligan SR. The feedback of exogeneous steroids on LH release and ovulation in the intact female vole (Microtus agrestis). J Reprod Fertil 1978; 54: 309-311.

150. Milligan SR. The effect of bromocriptine treatment on the ovulatory response to oestradiol benzoate in the reflex ovulator, Microtus agrestis. J Endocrinol 1980; 84: 315-316.

151. Milligan SR. Analysis of the LH surges induced by mating and LH-RH in the vole, Microtus agrestis. J Reprod Fertil 1981; 63: 39- 45.

152. Milligan SR. Induced ovulation in mammals. In: Finn CA, Ed. Oxford Reviews of Reproductive Biology. London: Clarendon Press, 1982: Vol 4, 1- 46.

153. Mitsushima D, Hei DL, Terasawa E. Gamma-aminobutyric acid is an inhibitory neurotransmitter restricting the release of luteinizing hormonerel easing hormone before the onset of puberty. Proc Natl Acad Sci USA 1994; 91: 395-399.

154. Mock OM, Conaway $\mathrm{CH}$. Reproduction of the least shrew. (Cryptitus parva) in captivity. In: Antikatzides Th, Spiegel A, Eds. The Laboratory Animal in the Study of Reproduction, $6^{\text {th }}$ symposium of the International Committee on Laboratory Animals, Thessal onika. Stuttgart: Fisher, 1976: 59-74.

155. Moenter SM, Karsch FJ, Lehman MN. Fos expression during the estradiol-induced gonadotropin-releasing hormone $(\mathrm{GnRH})$ surge of the ewe: Induction in $\mathrm{GnRH}$ and other neurons. Endocrinology 1993; 133: 896-903.

156. M offatt CA, Gerber J M, Blom J M, Kriegsfeld LJ , N elson RJ . Photoperiodic effects on steroid negative feedback in female prairie voles. Gen Comp Endocrinol 1995; 100: 92-95.

157. Moguilewskey M, Raynaud J -P. Estrogen-sensitive progestin-binding sites in the emale brain and pituitary. Brain Res 1979; 164: 165-175.

158. Moricard R. In: Wolstenholme GEW, Ed. Ciba Foundation Symposium: Mammalian Germ Cells. London: Churchill, 1953: 187-197.

159. Muske LE. Evolution of gonadotropin-releasing hormone (GnRH) neuronal systems. Brain Behav Evol 1993; 42: 215-230.

160. Nadler RD. A biphasic influence of progesterone on sexual receptivity of spayed female rats. Physiol Behav 1970; 5: 95-97.

161. Neill J D. Sexual differences in the hypothalamic regulation of prolactin secretion. Endocrinology 1972; 90: 1154-1159.

162. Nett TM, Crowder ME, Moss GE, Duello TM. GnRH-receptor interaction. V. Down-regulation of pituitary receptors for $\mathrm{GnRH}$ in overiectomized ewes by infusion of homologous hormone. Biol Reprod 1981; 24: 1145-1155.

163. Orstead KM, Spies HG. Inhibition of hypothalamic gonadotropin-rel easing hormone rel ease by endogenous opioid peptides in the female rabbit. Neuroendocrinology 1987; 46: 14-23.

164. Park O-K, Gugneja S, Mayo KE. Gonadotropin-releasing hormone gene expression during the rat estrous cycle: Effects of pentobarbital and ovarian steroids. Endocrinol ogy 1990; 127: 365-372. 
165. Parker GA. Sperm competition and its evolutionary consequences in the insects. Biol Rev 1970; 45: 525-567.

166. Pau K-YF, Khorram O, Kaynard AH, Spies HG. Simultaneous induction of neuropeptide Y and gonadotropin-rel easing hormone in the rabbit hypothalamus. Neuroendocrinol ogy 1989; 49: 197-201.

167. Pau K-YF, Lee CJ, Cowles A, Yang SP, Hess DL, Spies HG. Possible involvement of norepinephrine transporter activity in the pulsatility of hypothalamic gonadotropin-releasing hormone release: Influence of the gonad. J Neuroendocrinol 1998; 10: 21-29.

168. Pau K-YF, Ma YJ , Yu J, Yang SP, Airhart N, Spies HG. Topographic comparison of the expression of norepinephrine transporter, tyrosine hydroxylase and neuropeptide $Y$ mRNA in association with dopamine $\beta$-hydroxylase neurons in the rabbit brainstem. Mol Brain Res 1997; 48: 367-381.

169. Pau K-YF, Orstead KM, Hess DL, Spies HG. Feedback effects of ovarian steroids on the hypothalamic-hypophyseal axis in the rabbit. Biol Reprod 1986; 35: 1009-1023.

170. Pau K-YF, Spies HG. Estrogen-dependent effects of norepinephrine on hypothalamic gonadotropin-releasing hormone release in the rabbit. Brain Res 1986; 399: 15-23.

171. Petersen SL, Keller ML, Carder SA, McCrone S. Differential effects of estrogen and progesterone on levels of POMC mRNA levels in the arcuate nucleus: Relationship to the timing of LH surge release. J Neuroendocrinol 1993; 5: 643- 648.

172. Pfaus J G, J akok A, Kleopoulos SP, Gibbs RB, Pfaff DW. Sexual stimulation induces Fos immunoreactivity within GnRH neurons of the female rat preoptic area: Interaction with steroid hormones. Neuroendocrinol 1994; 60: 283-290.

173. Pfeiffer CA. Sexual differences of the hypophysis and their determination by the gonads. Am J Anat 1936; 58: 195-225.

174. Porkka-Heiskanen T, Urban J H, Turek FW, Levine J E. Gene expression in a subpopulation of luteinizing hormone-releasing hormone (LHRH) neurons prior to the preovulatory gonadotropin surge. J Neurosci 1994; 14: 5548-5558.

175. Price CS, Dyer KA, Coyne J A. Sperm competition between Drosophila males involves both displacement and incapacitation. Nature 1999; 400: 449- 452.

176. Rajendren G, Dudley CA, Moss RL. Influence of male rats on the luteinizing hormone releasing hormone neuronal system in female rats: Role of the vomeronasal organ. Neuroendocrinol 1993; 57: 898-906.

177. Ramirez VD, Chen J C, Nduka E, Lin W, Ramirez AD. Push-pull perfusion (PPP) of the hypothalamus and the caudate nucleus (CN) in conscious, unrestrained animals. Ann NY Acad Sci 1986a; 473: 434- 448.

178. Ramirez VD, Ramirez AD, Slamet W, Nduka E. Functional characteristics of the luteinizing hormone-releasing hormone pulse generator in conscious unrestrained female rabbits: Activation by norepinephrine. Endocrinology 1986; 118: 2331-2339.

179. Ramirez VD, Soufi WL. The neuroendocrine control of the rabbit ovarian cycle. In: Knobil E, Neill J D, Eds. The Physiology of Reproduction, 2nd ed. New York: Raven Press, 1994: 585- 612.

180. Richmond M, Stehn R. Olfaction and reproductive behavior in microtine rodents. In: Doty $\mathrm{RL}$, Ed, Mammalian Olfaction, Reproductive Processes, and Behavior. New York: Academic Press, 1976: 197-217.

181. Rissman EF. Behavioral regulation of gonadotropin-releasing hormone. Biol Reprod 1996; 54: 413-419.

182. Rissman EF, Clendenon AL, Krohmer RW. The role of androgens in the regulation of sexual behavior in the female musk shrew. Neuroendocrinology 1990; 51: 468- 473.

183. Rissman EF, Crews D. Hormonal correlates of sexual behavior in the female musk shrew: The role of estradiol. Physiol Behav 1988; 44: 1-7. 
184. Rissman EF, Li X. Sex differences in mammalian and chicken-II gonadotropin-releasing hormone immunoreactivity in musk shrew brain. Gen Comp Endocrinol 1998; 112: 346355.

185. Rissman EF, Silveira J, Bronson FH. Patterns of sexual receptivity in the female musk shrew (Suncus murinus). Horm Behav 1988; 22: 186-193.

186. Robinson A. XIII. The formation, rupture, and closure of ovarian follicles in ferrets and ferret-polecat hybrids, and some related phenomena. Trans R Soc Edinburgh 1918; 52: 303-362.

187. Roselli CE, Snipes CA. Cytoplasmic progestin receptors in the hypothalamus-preoptic area of the mouse. Effect of estradiol priming. J Steroid Biochem 1983; 19: 1571-1575.

188. Ryan KD. Hormonal correlates of photoperiod-induced puberty in a reflex ovulator, the female ferret. Biol Reprod 1984; 31: 925-935.

189. Sadlier RMFS. The Ecology of Reproduction in Wild and Domestic Animals. London: Methuen, 1969.

190. Sagrillo CA, Grattan DR, McCarthy MM, Selmanoff M. Hormonal and neurotransmitter regulation of $\mathrm{GnRH}$ gene expression and related reproductive behaviors. Behav Gen 1996; 26: 241-277.

191. Sarkar DK, Chaippa SA, Fink G, Sherwood NM. Gonadotrophin-releasing hormone surge in pro-oestrous rats. Nature 1976; 264: 461- 463.

192. Sarkar DK, Yen SS. Changes in beta-endorphin-like immunoreactivity in pituitary portal blood during the estrous cycle and after ovariectomy in rats. Endocrinology 1985; 116: 2075-2079.

193. Sawchenko PE, Swanson LW. The organization of noradrenergic pathways from the brainstem to the paraventricular and supraoptic nuclei in the rat. Brain Res Rev 1982; 257: 275-325.

194. Sawchenko PE, Swanson LW, Grzanna R, Howe PRC, Bloom SR, Polak J M. Col ocalization of neuropeptide $Y$ immunoreactivity in brainstem catecholaminergic neurons that project to the paraventricular nucleus of the hypothalamus. J Comp Neurol 1985; 241: 138-153.

195. Sawyer $\mathrm{CH}$. Stimulation of ovulation in the rabbit by intraventricular injection of epinephrine or norepinephrine. Anat Rec 1952; 112: 385.

196. Sawyer CH. Control of secretion of gonadotropins. In: Cole HH, Ed. Gonadotropins. San Francisco: Freeman, 1964: 113-159.

197. Sawyer $\mathrm{CH}$, Markee J E. Estrogen facilitation of release of pituitary ovulating hormone in the rabbit in response to vaginal stimulation. Endocrinology 1959; 65: 614- 621.

198. Sawyer $\mathrm{CH}$, Markee J E, Hollinshead WH. Inhibition of ovulation in the rabbit by the adrenergic-blocking agent dibenamine. Endocrinology 1947; 41: 395- 402.

199. Schally AV. Aspects of hypothalamic regulation of the pituitary gland. Science 1978; 202: 18-28.

200. Schiml PA, Rissman EF. Effects of gonadotropin-rel easing, corticotropin-releasing hormone, and vasopressin on female sexual behavior. Horm Behav 2000; 37: 212-220.

201. Schiml PA, Wersinger SR, Rissman EF. Behavioral activation of the female neuroendocrine axis. In: Wallen K, Schneider J E, Eds. Reproduction in Context: Social and Environmental Influences on Reproduction. MIT Press, 1999.

202. Schwagmeyer PL, Parker GA. Male mate choice as predicted by sperm competition in 13-lined ground squirrels. Nature 1990; 348: 62- 64.

203. Shivers BD, Harlan RE, Morrell JI, Pfaff DW. Absence of estradiol concentration in cell nuclei of LHRH-immunoreactive neurons. Nature 1984; 304: 345-347.

204. Signoret J P, du Mesnil du Buisson F, Mauléon P. Effect of mating on the onset and duration of ovulation in the sow. J Reprod Fertil 1972; 31: 327-330. 
205. Silverman AJ, Desnoyers P. Ultrastructural immunocytochemical localization of LHRH in the median eminence of the guinea pig. Cell Tissue Res 1976; 169: 157-166.

206. Skynner MJ, Sim J A, Herbison AE. Detection of estrogen receptor $\alpha$ and $\beta$ Messenger ribonucleic acids in adult gonadotropin-releasing hormone neurons. Endocrinology 1999; 140: 5195-5201.

207. Smith RL, Ed. Sperm Competition and the Evolution of Animal Mating Systems. Orlando: Academic Press, 1984.

208. Spies HG, Pau K-YF, Yang SP. Coital and estrogen signals: A contrast in the preovulatory neuroendocrine networks of rabbits and rhesus monkeys. Biol Reprod 1997; 56: 310-319.

209. Stockman ER, Albers HE, Baum MJ . Activity in the ferret: Oestradiol effects and circadian rhythms. Anim Behav 1985; 33: 150-154.

210. Sullivan KA, Witkin J W, Ferin M, Silverman AJ. Gonadotropin-releasing hormone neurons in the rhesus macaque are not immunoreactive for the estrogen receptor. Brain Res 1995; 685: 198-200.

211. Tang YP, Kashon ML, Sisk CL. Brain region-specific regulation of luteinizing hormonereleasing hormone messsenger ribonucleic acid in the male ferret: Interactions between pubertal maturation and testosterone. Endocrinology 1997; 138: 4740- 4747.

212. Terkel J. Neuroendocrine processes in the establishment of pregnancy and pseudopregnancy in rats. Psychoneuroendocrinology 1988; 13: 5-28.

213. Thind KK, Goldsmith PC. I nfundibular gonadotropin-releasing hormone neurons are inhibited by direct opioid and autoregulatory synapses in juvenile monkeys. Neuroendocrinology 1988; 47: 203-216.

214. Traczyk WZ, Pau K-YF, Kaynard AH, Spies HG. Modulatory role of substance P on gonadotropin and prolactin secretion in the rabbit. J Physiol Pharmacol 1992; 43: 279-297.

215. Tsuruo Y, Hitoshi K, Hisano S, Kagotani Y, Daikoku S, Zang T, Yanaihara N. Substance P-containing neurons innervating LHRH-containing neurons in the septo-preoptic area of rats. Neuroendocrinology 1991; 53: 236-245.

216. Turzillo AM, Di Gregoria GB, Nett TM. Messenger ribonucleic acid for gonadotropinreleasing hormone receptor and numbers of gonadotropin-releasing hormone receptors in ovariectomized ewes after hypothalamic-pituitary disconnection and treatment with estradiol. J Anim Sci 1995; 73: 1784-1788.

217. Van der Beek EM, Horvath TL, Wiegant VM, Van den Hurk R, Buijs RM. Evidence for a direct neuronal pathway from the suprachiasmatic nucleus to the gonadotropin-releasing hormone system: Combined tracing and light and electron microscopic immunocytochemical studies. J Comp Neurol 1997; 384: 569-579.

218. Versi E, Chiappa SA, Fink G, Charlton HM. Effect of copulation on the hypothalamic content of gonadotrophic hormonereleasing hormone in the vole, Microtus agrestis. J Reprod Fertil 1982; 64: 491- 494.

219. Villars TA, Erskine MS, Lambert GM, J acobson D, Weaver DE, Baum MJ. Endocrine correlates of mating-induced reductions in estrous behavior in an induced ovulator. Horm Behav 1990; 24: 198-214.

220. Vreeburg J T, van der Vaart PD, van der Schoot P. Prevention of central defeminization but not masculinization in male rats by inhibition neonatally by oestrogen biosynthesis. J Endocrinol 1977; 74: 375-382.

221. Wang CF, Lasley BL, Lein A, Yen SSG. A functional change of the pituitary gonadotrophs during the menstrual cycle. J Clin Endocrinol Metab 1976; 42: 718-728.

222. Warembourg M, Leroy D, Peytevin J, Martinet L. Estrogen receptor and progesterone receptor-immunoreactive cells are not co-localized with gonadotropin-releasing hormone in the brain of the female mink (Mustela vison). Cell Tissue Res 1998; 291: 33- 41. 
223. Waring DW, Turgeon J L. Luteinizing hormone-releasing hormone-induced luteinizing hormone secretion in vitro: Cyclic changes in responsiveness and self-priming. Endocrinology 1980; 106: 1430-1436.

224. Watson RE, Langub MC, Landis J W. Further evidence that most luteinizing hormonereleasing hormone neurons are not directly estrogen-responsive: Simultaneous localization of luteinizing hormone-releasing hormone and estrogen receptor immunoreactivity in the guinea pig brain. J Neuroendocrinol 1992; 4: 311-317.

225. Watts AG, Fink G. Constant light blocks diurnal but not pulsatile release of luteinizing hormone in the ovariectomized rat. J Endocrinol 1981; 89: 141-146.

226. Weiland NG, Barraclough CA. Neonatal castration of male and female rats affects luteinizing hormone responses to estrogen during adulthood. Biol Reprod 1984; 31: 942-949.

227. Wersinger SR, Baum MJ . The temporal pattern of mating-induced immediate early-gene product immunoreactivity in LHRH and non-LHRH neurons of the estrous ferret forebrain. J Neuroendocrinol 1996; 8: 345-359.

228. Wersinger SR, Baum MJ . Sexually dimorphic processing of somatosensory and chemosensory inputs to forebrain luteinizing hormonereleasing hormone neurons in mated ferrets. Endocrinology 1997; 138: 1121-1129.

229. Wersinger SR, Baum MJ . Sexually dimorphic activation of midbrain tyrosine hydroxylase neurons after mating or exposure to chemosensory cues in the ferret. Biol Reprod 1997; 56: 1407-1414.

230. Whalen RE. Sexual behavior of cats. Behaviour 1963; 20: 321-342.

231. Whalen RE, Hardy DF. Induction of receptivity in female rats with oestrogen and testosterone. Physiol Behav 1970; 5: 529-533.

232. White RB, Eisen JA, Kasten J L, Fernald RD. Second gene for gonadotropin releasing hormone in humans. Proc Natl Acad Sci USA 1998; 95: 305-309.

233. Whitney LF, Underwood AB. The Racoon. Orange, Connecticut: Practical Science, 1952.

234. Whitten WK. Pheromones and mammalian reproduction. In: McLaren A, Ed. Advances in Reproductive Physiology. New York: Academic Press, 1966: 155-177.

235. Wiemann J N, Clifton DK, Steiner RA. Gonadotropin-releasing hormone messenger ribonucleic acid levels are unaltered with changes in the gonadal hormone milieu of the adult male rat. Endocrinology 1990; 127: 523-532.

236. Wildt DE, Chan SYW, Seager SWJ , Chakrabory PK. Ovarian activity, circulating hormones, and sexual behavior in the cat. I. Relationships during the coitus-induced luteal phase and the estrous period without mating. Biol Reprod 1981; 25: 15-28.

237. Wildt DE, Guthrie SC, Seager SWJ . Ovarian and behavioral cyclicity of the laboratory maintained cat. Horm Behav 1978; 10: 251-257.

238. Wildt DE, Seager SWJ, Chakraborty PK. Effect of copulatory stimuli on incidence of ovulation and on serum luteinizing hormone in the cat. Endorinology 1980; 107: 1212-1217.

239. Wise ME, Nieman D, Stewart J , Nett TM. Effect of number of receptors for gonadotropinreleasing hormone on the release of luteinizing hormone. Biol Reprod 1984; 31: 1007-1013.

240. Witkin J W, Silverman AJ. Synaptology of LHRH neurons in the rat preoptic area. Peptides 1985; 6: 263-271.

241. Wood RI, Newman SW, Lehman MN, Foster DL. GnRH neurons in the fetal lamb hypothalamus are similar in males and females. Neuroendocrinology 1992; 55: 427- 433.

242. Wray S, Gainer H. Effect of neonatal gonadectomy on the postnatal development of LHRH cell subtypes in male and female rats. Neuroendocrinology 1987; 45: 413- 419.

243. Wray S, Hoffman G. A developmental study of the quantitative distribution of LHRH neurons within the central nervous system of postnatal male and female rats. J Comp Neurol 1986; 252: 522-531. 
244. Wright $D E$, J ennes L. Origin of noradrenergic projections to $G n R H$ perikarya-containing areas in the medial septum-diagonal band and preoptic area. Brain Res 1993; 621: 272-278.

245. Wu TJ, Segal AZ, Miller GM, Gibson MJ . FOS expression in gonadotropin-releasing hormone neurons: Enhancement by steroid treatment and mating. Endocrinology 1992; 131: 2045-2050.

246. Yang SP, Pau K-YF, Airhart N, Spies HG. Attenuation of gonadotropin-releasing hormone reflex to coitus by al phal-adrenergic receptor blockade in the rabbit. Proc Soc Exp Biol Med 1998; 218: 204-209.

247. Yang SP, Pau K-YF, Hess DL, Spies HG. Sexual dimorphism in secretion of hypothalamic gonadotropin-releasing hormone and norepinephrine after coitus in rabbits. Endocrinology 1996; 137: 2683-2693.

248. Yang SP, Pau K-YF, Spies HG. Tyrosine hydroxylase and norepinephrine transporter mRNA levels increase in locus coeruleus after coitus in rabbits. J Mol Endocrinol 1997; 19: 311-319.

249. Yen SS, Quigley ME, Reid RL, Ropert J F, Cetel NS. Neuroendocrinology of opioid peptides and their role in the control of gonadotropin and prolactin secretion. Am J Obstet Gynecol 1985; 152: 485- 493.

250. Younglai EV, Wilkinson M, Thompson N. Effects of ovariectomy and estradiol replacement on naloxone induced LH secretion in the female rabbit. J Steroid Biochem 1988; 29: 347-351.

251. Zarrow $\mathrm{MX}$, Clark J H. Ovulation following vaginal stimulation in a spontaneous ovulator and its implications. J Endocrinol 1968; 69: 183-191.

252. Zoeller RT, Seeburg PH, Y oung WS III. In situ hybridization histochemistry for messenger ribonculeic acid (mRNA) encoding gonadotropin-releasing hormone $(\mathrm{GnRH})$ : Effect of estrogen on cellular levels of GnRH mRNA in female rat brain. Endocrinology 1988; 122: 2570-2577.

253. Zohar Y, Elizur A, Sherwood NM, Powell J FF, Rivier J E, Zmora N. Gonadotropin-releasing activities of the three native forms of gonadotropin-releasing hormones present in the brain of gilthead seabream, Sparus aurata. Gen Comp Endocrinol 1995; 97: 289-299.

254. Zucker I, Goy RW. Sexual receptivity in the guinea pig: I nhibitory and faciltatory actions of progesterone and related compounds. J Comp Physiol Psychol 1967; 64: 378-383. 